\title{
Seferihisar Mevcut Bisiklet Güzergâhlarının CBS Ortamında Şehrin Dirençliliği Yönünden Yavaş Şehir Kriterlerine Göre Değerlendirilmesi
}

\author{
Özşen ÇORUMLUOĞLU ${ }^{1 *}$ ve Çağlayan Şafak KAZMA²
}

\section{Öz}

Yavaş Şehir kavramı, önceleri İtalya'da yavaş yeme hareketi şeklinde ortaya çıkmış, zaman içerisinde gelişerek Yavaş Şehir yaşam tarzına dönüşmüş ve dünyanın pek çok farklı yöresinde yankı bulmuş bir şehircilik yaklaşımı olarak karşımıza çıkmaktadır. Günümüz şehirlerindeki hızlı yaşam tarzına alternatif, insan ve etkileşim içerisinde olduğu çevre açısından daha sürdürülebilir bir yaşam ve buna uygun şehirsel yapılanmayı önceleyen bir hareket olarak benimsenmektedir. Zaman içerisinde kurumsallaşan yavaş şehir yaklaşımı, merkezi İtalya Orvieto kenti olan dünya çapında bir harekete dönüşmüştür. Bu harekete katılmak isteyen şehirlerden de bazı kriterleri sağlamaları istenmektedir.

Toplamda 72 maddeden oluşan bu Yavaş Şehir olma kriterlerinden bir kısmı, şehri daha sakin hale getirmek için gerek turistler gerekse de şehir halkı tarafından bisiklet kullanımını önceleyen şartlardır. Keza, bu şartların yerine getirilmesiyle şehir; daha yaşanabilir, daha konforlu ve özelikle de doğal çevrenin korunması açısından sürdürülebilir hale gelmektedir. Diğer taraftan şehirde bisiklet kullanımını yaygınlaştırmayı amaçlayan bu kriterler sayesinde, özellikle ulaşım açısından, teknolojiyi dışlamadan, fakat zararlarını minimize edecek cazıp bir alternatif çözüm de oluşturulabilmektedir. Bunun da şehri daha dayanıklı ve dirençli kıldığı görülmektedir. Bütün bunlar aşığında öncelikli olarak bisiklet kullanımına yönelik şehrin mevcut durum analizinin ve nelerin yapılması gerektiğinin ortaya konması önemlidir. Bu konuda gerçekleştirilen iyileştirmeler, özellikle doğasever, çevreci ve yavaş yaşamı önceleyen turist grupları için de şehri çok daha çekici hale getirmektedir. Bu sayede, şehrin doğalı korunurken, ekonomik, kültürel ve sosyolojik açıdan kalkınmasına da katkıda bulunulabilmektedir.

Bu çalışmada, Seferihisar için planlanmış mevcut bisiklet yollarının Yavaş Şehir kriterlerine göre CBS ortamında analizleri gerçekleştirilmiştir. Bu analizler ve sonuçları ile aslında, şehrin doğal çevre açısından ne kadar sürdürülebilir olduğu ve çevresel dirençliliği de ortaya konmaktadır. Bu bağlamda Seferihisar mevcut bisiklet yollarının güzergah konforu açısından yeşil alanlara yakınlığı, su kitlelerine yakınlığı, aydınlatma, kentsel donatılara yakınlığı, kamu kurumlarına yakınlığı gibi analizler CBS ortamında gerçekleştirilmiş ve mevcut durumun sonuçları paylaşılmıştır.

Anahtar Kelimeler: Yavaş Şehir, Bisiklet güzergahı, Dirençlilik, CBS

\footnotetext{
${ }^{1}$ İzmir Katip Çelebi Üniversitesi, Harita Mühendisliği Bölümü, İzmir, Türkiye

${ }^{2}$ İzmir Katip Çelebi Üniversitesi, Kentsel Dönüşüm ABD, İzmir, Türkiye

*ilgili yazar / Corresponding author: ocorumlu@hotmail.com, ozsen.corumluoglu@ikc.edu.tr

Gönderim Tarihi / Received Date: 23.05.2019

Kabul Tarihi / Accepted Date: 29.05.2019
}

Bu makaleye atıf yapmak için- To cite this article Çorumluoğlu, Ö., \& Kazma, Ç. (2020). Seferihisar Mevcut Bisiklet Güzergâhlarıın CBS Ortamında Şehrin Dirençliliği Yönünden Yavaş Şehir 


\title{
Evaluation of Current Bike Roads of Seferihisar According to Slow City Criteria for City Resilience in GIS Environment
}

\begin{abstract}
Cittaslow approach first has been seen in Italy after a slowfood movement emerged against fastfood habit in our modern cities to prevent our citizens and environments from an unhealthy life style. The slow city approach has turned into a worldwide movement over time and then become an organization with the center of which is the city of Orvieto, Italy. Cities who want to join this movement have also been asked to comply with some criteria.
\end{abstract}

Some of the criteria for being a slow city which it has totally 72 are about criteria prioritizing the use of bicycle by tourist and residents of the Cittaslow. So, this will make the city more livable, push it to increase its comfort level, and then make it sustainable, especially in terms of preserving the natural environment, it also becomes more resilient. Thus, an attractive alternative will be created that does not exclude technology, especially in terms of transportation, but will minimize its side and destructive effects. This will make the city more resilience and makes it more durable. In all of these, the city's current situation in terms of bicycle use and further what should be done should be revealed. With the improvements, the city can become attractive, especially for groups of tourists who like nature, be in environment and slow life. In this way, while the nature of the city is preserved, it will contribute the city's economic, cultural and sociologic development.

In this study, the existing bicycle routes in Seferihisar were analyzed against the cittaslow criteria in a GIS environment. With these analyzes and their results, the sustainability of the city in terms of its natural environment and its environmental resilience are also revealed. In this context, analyzes such as the proximity of the existing bicycle roads to green areas, proximity to water masses, lighting, proximity to urban facilities, and proximity to public institutions were carried out in the GIS environment and the results from this study are shared in the paper.

Keywords : Cittaslow, Bicycle Routes, Resilience, GIS

\section{GiRiş}

Geçtiğimiz yüzyılın son çeyreği ve bu yüzyılın başında, gelişmiş ve gelişmekte olan ülkelerdeki nüfusun büyük bir çoğunluğu kırsaldan kentsel alanlara göç ettiği için bu ülkelerin nüfusları şehirlerde yoğunlaşmaya başlamıştır. Bu artış hız kesmeden devam etmekte ve yavaşlayacak gibi de gözükmemektedir. Nüfus göçünün bu baskısından kentleri koruyabilmek ve yaşanılabilirlik seviyelerini sürdürülebilir kılabilmek, şehirlerde etkin yönetimbilişim sistemleri desteğinde etkin alternatif çözümler oluşturabilmekle mümkün olacaktır. Öyle ki, artan şehir nüfusunun doğal alanlar üzerinde oluşturduğu baskı ve neticede hızlı bir biçimde bu alanların yok edilmesi kentlerin sürdürülebilirlik planlamalarını ciddi derecede tehlikeye sokmaktadır. CBS, sürdürülebilir kent yönetimi konusunda; altyapıdan üstyapıya, planlamadan sağlığa, güvenlikten ulaşıma, eğitimden turizme kısaca kentlerin yönetiminde sürdürülebilir planlamanın intiyaç duyulduğu hemen hemen her alanda yukarıda sayılan faydaları sağlayan vazgeçilemez ve yegane konum tabanlı bir bilgi sistemi olarak dünya gündemine girmiş bulunmaktadır. Yarının şehirleri, özellikle CBS gibi çağdaş, etkin ve anlık sorgulamalara olanak sağlayan sayısal bir taban üzerinden yönetilebilir kılınmadıkları sürece sürdürülebilir ve yaşanabilir kentler olamayacaklardır. 
Kent sistemleri son derece girift, karmaşık aşırı (hiper) kriterli yapılar olduklarından tam olarak modellenebilecekleri de tahmin edilememektedir (Li \& Yeh, 2001). Karmaşık sistemlerin çevreye etkileri; verdikleri tahribatın çözümlenemediği oranda yüksek olmaktadır. Kent gelişiminin neden olduğu çevreye verilen bu tahribatın boyutlarının farkına varılması ile günümüz kentleri; sürdürülebilir çözümler üreterek, gerek bugünkü ve gerekse de gelecekteki kentsel yaşam standardının yükseltilmesi gerektiğini anlamaya başlamalarıyla birlikte, kentsel dönüşüm ve değişime gitmeyi gündemlerine almaya başlamışlardır. Bu tip arayışlar, mevcut şehir sistemleri korunurken gelişimi de engellemeden sürdürülebilirlik çerçevesinde kalan çözümlerin ortaya konduğu değişik yaklaşım ve kavramların ortaya çıkmasına da neden olmuştur. Bunlardan biri de literatürde "Resilience" olarak geçen Türkçeye de "dayanıklılık" veya "dirençlilik" olarak çevrilen kavramıdır. Bir diğeri ise, "Slow City" veya "Slow City Movement" olarak literatürde yer alan ve Türkçeye de "Yavaş Şehir" veya "Yavaş Şehir Hareketi" olarak çevrilen kentsel yaşam tarzıdır. Bu hareket, birliğe katılan şehirler için uymaları gereken pek çok kriter ortaya koymuştur. Bu kriterlerden bazıları da şehrin sürdürülebilir doğal yapısı açısından önem arz eden ve şehirde bisiklet kullanımını önceleyen, bir bakıma da düzenleyen kriterleri içermektedir.

Türkçe de "Dirençlilik" olarak ifade edilen "Resilience" kavramsal olarak Afet Risk Azaltma Uluslararası Ofisi (UNISDR) Hyogo Eylem Planı sonuç raporunda (2007), "tehlikelere maruz kalmış bir sistemin, topluluğun veya toplumun, kendi temel yapılarını ve işlevlerini koruma ve onarma dahil, bir tehlikenin etkileri karşısında zamanında ve etkin bir şekilde direnme, soğurma, uyum geliştirme ve iyileşme becerisi" olarak tanımlanmaktadır. Önceki paragraflarda açıklananlar ışığında günümüz şehirlerinin içinde bulunduğu durumun, bu paragrafın başında geçen ve Dirençlilik tanımında yer alan "tehlikelere maruz kalmış sistemler" ifadesi göz önüne alındığında, yavaş şehir kriterleri arasında yer alan ve şehrin mevcut doğallığının bozulmasının karşısında duracak bir çözüm olarak görülen bisiklet kullanımını önceleyen ve bu kullanımı artırıcı özelliklere sahip bisiklet güzergah ve yollarının oluşturulmasını öneren kriterlerin sağlanması; şehirsel gelişim süreçleri içerisinde doğal olarak şehirlerin içerisinde üretilmeyip dışarısından gelen ve yaşanılan yüzyılın teknolojik bir baskısı olarak ortaya çıkan, şehirde fosil yakıtla çalışan motorlu taşıt kullanımına karşı bir direnç ve alternatif bir çözüm oluşturacaktır. Kısacası, şehrin mevcuttaki doğal, gürültüsüz ve temiz çevre özelliğinin koruması açısından şehrin direnç ve dayanıkıı̆ı̆ına pozitif bir katkı oluşacaktır. Bu sayede (şehrin dirençliliği açısından), şehrin karşı karşıya kaldığı tehlikelerin etkilerine zamanında ve etkin bir şekilde direnme, soğurma, uyum geliştirme ve iyileşme becerisi göstermesine de olanak sağlanacaktır. Bu da, şehrin kalkınmasına engel oluşturmadan sürdürülebilir bir tabana oturtulmasına olanak verecektir.

Sürdürülebilir kalkınma kapsamında ifade edilen; biyolojik çeşitlilik kaybının ve çölleşmenin önlenmesi, iklim değişikliği ile mücadele edilmesi ve uyum sağlanması, doğal kaynakların sürdürülebilir kullanılması, gelir dağııımını düzelterek ve istihdam yaratarak yoksullukla mücadele edilmesi, eğitim ve sağlık hizmetlerinin kalitesinin yükseltilmesi ve bunlara erişimin artırılması, temiz suya, güvenli enerji kaynaklarına ve gıdaya erişimin artırılması gibi konular, dirençlilik ve sürdürülebilirlik açısından da geleceğin kentlerini yapısal olarak şekillendirecek ve kentlerindeki yaşam tarzını da doğrudan etkileyecek konular olarak karşımıza çıkmaktadır (Kalkınma Bakanlığı, 2012). Günümüz kentlerinde hızlı yaşamın genel yaşam tarzı halini aldığı bu günlerde kentlerdeki günlük hayatın daha sürdürülebilir kılınması ve kentleri dirençli kılmak için, Yavaş Şehir anlayışının getirdiği kentsel yaşam kriterleri ile yukarıda belirtilen kentsel sürdürülebilir kalkınma ve dirençliliğin amaçları birlikte değerlendirildiğinde, yavaş şehir hareketi kapsamında gerçekleştirilmesi gereken kriterlerin; küçük kentlerin sürdürülebilir kalkınmasına yardımcı olma ve ayrıca bu tür kentleri dirençli kılma noktasında ciddi katkılar sağlama potansiyeline sahip olduğu görülebilmektedir. Kazma'nın (2017, s. 82) tezinde de belirtildiği gibi, yavaş şehirlerin gerek sürdürülebilirliğinin sağlanması, gerekse de bu kentlerin 
sahip olduğu değerler ile doğal çevrelerinin yok edilmesine engel olunarak dirençli kılınması için etkin bir yönetim destek sistemine duyulan gereksinim açıktır. Bu bağlamada, CBS gibi konum tabanlı bir bilgi sisteminin, bu tür bir kent yönetim sistemine entegre edilmesi son derece önemli olup, CBS ortamında gerçekleştirilecek durum analizlerinde, karar vermeye yönelik çok kriterli değerlendirmelerde, gelecek perspektiyle yapılacak planlamaların tasarımından uygulanmasına ve hatta sonrasına kadar ki pek çok aşamanın daha doğru bir biçimde uygulanmasında, bunun da ötesinde stratejik olarak, bu yerleşim yerlerindeki kalkınmanın sürdürülebilir kııınmasında ve şehrin dirençliliğine katkı sağlamada da etkin bir role sahip olacağı düşünülmektedir.

Bu çalışmada, Türkiye'nin ilk yavaş şehir başşehri olan Seferihisar örneğinde, yavaş şehir yaklaşımındaki yavaş şehir kriterleri kapsamında yer alan bisiklet yolları kriterlerine göre şehrin mevcut durumunu ortaya koymak için, CBS'nin sunduğu olanaklardan faydalanılarak bir dizi konumsal analiz gerçekleştirilmiş ve bu analizlerin sonuçları paylaşılarak yörenin, mevcut bisiklet yol ve güzergahları bağlamında çevresel sürdürülebilirlik ve dirençlilik açısından değerlendirilmesine çalışılmıştır. Bu nedenle çalışma, CBS ortamında gerçekleştirilen yavaş şehir kriter analizlerinden sadece bisiklet yolları ile alakalı olanları içerecek şekilde kısıtlı tutulmuştur.

\subsection{Sürdürülebilirlik, Dayanıklılık ve/veya Dirençlilik}

İnsanlığın 20. yüzyılda endüstriyel ve teknolojik açıdan geldiği nokta her ne kadar baş döndürücü ve bir o kadar da çarpıcı olsa dahi, vahşice kaynak kullanımı nedeniyle artan işletme maliyetleri ve bunun neticesinde de 70'lerde yaşanan ekonomik sorunlar, işletmelerin sürdürülebilirliğinin sorgulanmasını gündeme getirmiş ve bu durum aynı zamanda yaşanan ekolojik sorunların da farkına varılmasına ve dikkate alınmasına vesile olmuştur. Böylece, en bilinen şekli ile bugünün gereksinimlerinin gelecek kuşakların gereksinimlerini tehlikeye atmadan karşılanması esasına dayanan kalkınma şekli olarak tanımlanan sürdürülebilirlik; 1980'lerden sonra ekolojik yönü ile de irdelenen bir kavram haline gelmiştir (IIED,1987).

20. ve 21. yüzyıl toplumları umursamaz bir şekilde ürettiklerinden çok daha fazlasını tüketiyor, doğal kaynaklarını aşındırıyor ve kirletiyor olsalar da, dünya, birbiriyle etkileşim halinde sonsuz sayıda unsurdan oluşmuş bir sistem olarak düşünüldüğünde, sürdürülebilirlik kavramı esasta; dünyanın geneline ait olan bütün doğal kaynakların gelecek kuşaklara da aktarılabilmesi için gelişmenin yan etkilerinin kontrol altına alınması gerektiği fikrine dayanmaktadır (Leanne Barron and Erin Gauntlett, 2002).

Ekonomik çıkmazların tetiklediği farkındalıkla aynı düşünceleri paylaşanların bir araya gelmesiyle oluşan çevreci hareketler, sürdürebilirlik kavramının çıkış noktasını oluşturmuş ve 1987 'de Brundtland Komisyonunun "Ortak Geleceğimiz" adlı raporu ile insan etkisiyle doğal çevreye verilen her türlü zarar da, küresel bir problem olarak kabul edilmiştir (IIED,1987). Bu raporda, ekonomik gelişme, yaşam kalitesi ve çevresel kalitenin korunmasına dayanan üçayaklı sürdürülebilir bir gelişime tarzının, tüm ülkelerin ve tüm ülke vatandaşlarının uyum sağlaması gereken bir sorumluk olduğu ortaya konmuştur (IIED,1987). Bu nedenle, günümüzde yoğun bir nüfuz baskısına maruz kalan kentlerimizin ve bu akımın ters etkisiyle yaşam mücadelesi veren küçük kentlerimizin sürdürülebilir gelişiminin sağlanması ve bu gelişimin planlanması, çağımızın en önemli konularından biri haline gelmiştir.

Yerleşmeler, sürdürülebilirlik ilkesi çerçevesinde gelecek nesillerin yaşam alanlarını planlarken, onlar için de; yeterli temiz hava, su, toprak ve enerji bulunmasını garantilemek durumundadırlar. Bu nedenle, herhangi bir şehrin gelişimini sürdürülebilir kılacak şekilde gerçekleştirilen planlama ve tasarım çalışmaları ile şehirlerin sürdürülebilirliği yönünde 
belirlenen yönetim politikaları ve bu politikaların yansıması olarak alınan kararlar, gün geçtikçe çok daha önemli hale gelmektedir. Böyle bir planlama anlayışının ortaya çıkardığı yansımalardan biri de örneğin, ekosistem duyarlı planlama yaklaşımı olarak karşımıza çıkar. Ekosistem duyarlı planlama yaklaşımlarının odak noktasını ise, herhangi bir yerdeki mevcut ekosistemin sürdürülür kılınmasının yanı sıra insan yaşam kalitesindeki artışın da sürdürülebilir kılınması oluşturur (MA, Ecosystem and Human Wellbeing, 2005; Ndubisi, 2005). Ekosistemin sürdürülebilirliğini esas alan planlama yaklaşımlarının; mevcut ekosistemlerin sürdürülebilirliğini sağlayacak şekilde belirlediği kaynak sağlayıcı, düzenleyici, kültürel ve destekleyici işlevlere uygun bir yerleşim planlaması ile insan yaşam kalitesini arttırırken, çağdaş gereksinimleri de karşılayacak yönetim politikalarını içermesi gerekmektedir (MA, 2005). Böyle bir planlama yaklaşımının kentsel yansıması ise, kentsel sürdürülebilir gelişmeyi esas alırken kentsel sürdürülebilir-ekosistem hedefini odaklayan bir planlama yaklaşımı olmaktadır.

Benzer şekilde dayanıklııı da, bir kanadıyla, mevcut ekosistemlerin sürdürülebilirliği konusunu esas alan diğer bir kavram olarak karşımıza çıkmaktadır (Holling, 1973; Folke, 2006). Kavram literatürde, farklı araştırma konularında yaygın bir şekilde geçse de, sürdürülebilir gelişmeyi amaçlayan çalışmalarda da gün geçtikçe daha fazla kullanılmaya başlanmıştır (Folke, 2006). Hatta, kentsel çalışmaların bazılarında da, kentsel dayanıklılık tanımıyla karşılaşılabilmektedir (Carmin, Nadkarni, \& Rhie, 2012; Leichenko, 2011).

Dayanıklıık; değişimleri, riskleri ve sürprizleri önleme veya bu tür belirsizliklere ayak uydurarak sistemin sürdürülebilirliğinin sağlanması olarak ifade edilmektedir (Holling, 1973; Folke, 2006). Kentsel dayanıklılık ise, kentlerin sosyal, ekonomik, ekolojik ve yapılı çevreleri ile çok karmaşık sistemler olmalarına rağmen, mevcut kırılganlıklarıyla birlikte bu karmaşık sistemlerin de, değişimlere ve belirsizliklere karşı dayanıklı olabilmeleri anlamını taşır (Meerow vd. 2016). Yukarıda belirtilen uluslararası raporlarda geçen vurgular üzerinde dizayn edilen böyle bir çağdaş kentleşme olgusu ulaşılacak hedef olarak belirlendiğinde, kentsel dayanıklılık konusunun, sürdürülebilir gelişme açısından büyük bir öneme sahip ve vazgeçilemez olduğu görülecektir. Bu durumda, kentsel planlama ve tasarım çalışmalarında dayanıkı kent yaklaşımının benimsenmesi yaşadığımız çağın bir gerekliliği olarak karşımıza çıkmaktadır.

Dayanıklııı bir sistem olarak tanımlandığı için, değişimleri, riskleri, belirsizlikleri tespit ederek bunları gerek minimize edecek gerekse de önleyecek tedbirlerin alınması da olmazsa olmaz gereklilik halini almaktadır. Bu noktada da, ilk yapılması gerekenler ise, gerekli tanımlamaları yaparak çözüm üretmeye ve sistemi yönetmeye yönelik gerekli araçların geliştirilip üretilmesidir.

Kent birçok unsurun bir araya gelmesinden oluşan bir bütün olduğu için kentsel dayanıklılık da bütüncül olarak ele alınmalıdır. Bu nedenle, gerek sosyal dayanıklılık, gerek ekolojik dayanıklılık ve gerekse de afetlere karşı dayanıklılık konularının tümüne birbiriyle etkileşimde olan bir bütünün parçaları olarak yaklaşılmalı ve değerlendirmeler bu bakış açısıyla gerçekleştirilmelidir ki, oluşabilecek muhtemel kırılganlıkların önüne geçilip kentsel dayanıklılık da sürdürülebilir kılınabilsin. Kentsel dayanıklıı̆ın gerçekleştirilebilmesi ve sürdürülebilirliği için sosyo-ekolojik ilişki ağlarının canlandırılması (örneğin bisiklet sever turist gruplarına ulaşılarak tercihlerinin yönlendirilmesi) ve ekolojik yapılaşmanın sağlanması için gerekli hedeflerin belirlenerek, bu hedeflerin gerçekleştirilebilmesi için sosyal, ekonomik ve ekolojik politikalar geliştirilmesi, ardından da bu politikaları gerçekleştirebilecek planlama yöntem ve araçlarının tespit edilmesi önemlidir (Altun, 2011).

Sürdürülebilir ve ekolojik kentsel gelişim kapsamında göz önünde bulundurulabilecek olan ve yavaş şehir yaklaşımında da yer bulan bisiklet kullanımı ile bisiklet yol ve güzergahlarının 
oluşturulması ve iyileştirilmesi gibi konular; kentsel dayanıklılığın arttırılması için geliştirilecek ekolojik olarak sürdürülebilir kentsel gelişim planları ve tasarım stratejilerinde kullanılabilecek yöntem ve araçlar arasında değerlendirilebilirler.

$\mathrm{Bu}$ çalışmada kentsel dayanıklılık çözümlemeleri kapsamında, Seferihisar örneğinde gerçekleştirilen yavaş şehir uygulamaları bir fırsat olarak değerlendirilmiş ve gerek bölgedeki ekosistemin sürdürülebilirliği açısından gerekse de bu noktada kentsel dayanıklılığa vereceği katkıdan dolayı, bölge ve şehirdeki bisiklet kullanımının (gerek turist çekerek gerekse de yerel halkın kullanımının) yaygınlaştırıması hedeflenerek, halihazırda var olan bisiklet güzergahlarının mevcut durumları; konum tabanlı (Geospatial) teknolojiler yardımıyla analiz edilip, iyileştirilmeleri adına mevcudun nerede durduğu ortaya konmaya ve vurgulanmaya çalışılmıştır.

\section{YAVAŞ ŞEHIR KAVRAM VE YAKLAŞIMI}

İnsanoğlunun son bir yüzyıl içerisinde gerçekleştirdiği evrimsel dönüşüm daha önceki dönemler ile karşılaştırıldığında, bu yüzyılın en hızlı yüzyıl olduğu ifade edilmektedir. Toplumların yaşamlarına yön veren icatların bulunmasıyla insan hayatındaki "zaman" kavramı hiç olmadığı kadar değerlenmiş ve buna paralel olarak da insanoğlunun hayatında "hız", daha önce hiç karşılaşılmayan bir öneme sahip olmuştur. Gelişen kentlerde hayıtın hızıı akışı bir tarafa, kırsaldan kentsele göçün de hızla artması kentsel nüfuzun da hızla yükselmesine neden olmuş ve bu durum da, kentsel intiyaçların giderek artması ve çeşitlenmesi sonucunu doğurmuştur. Daha önce de bahsedildiği gibi kırsaldan ketlere doğru gerçekleşen bu yoğun nüfuz akışı, kentin mevcut kaynakları üzerinde ciddi bir baskı oluşturmuş ve beraberinde de yanlış arazi kullanımını getirmiştir. Böylece, arazi kaynaklarının tahrip edilmesine ve yoksulluk başta olmak üzere çok çeşitli sosyal problemlerin yaşanmasına zemin hazırlanmıştır (FAO, 1976).

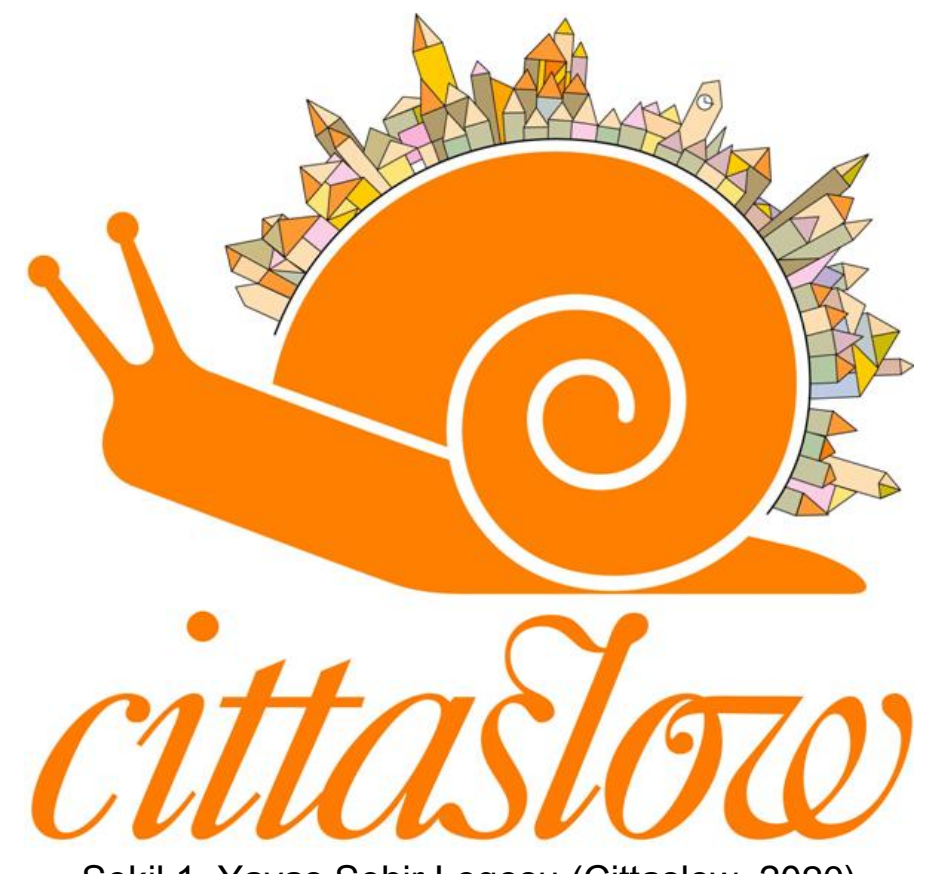

Şekil 1. Yavaş Şehir Logosu (Cittaslow, 2020)

Yavaş şehir, endüstri devrimi ile birlikte belirgin hale gelen hız kavramına karşı "Slow Food" akımından temel alınarak ortaya çıkarılmış olan ve yenilikçi teknolojik gelişmelerin günden güne ve sürekli olarak artan yoğun baskısı karşısında; geleneklerin, kültürel mirasın, yerellik 
kavramının ve sürdürülebilirliğin önemini savunan bir yavaşlık hareketini ifade eder (Cittaslow, 2020).

Yavaşlık anlayışı, dünya genelinde oluşan algıya göre, "hız" kavramına karşıt duruyor gibi gözükmektedir. Ancak, yavaşlık; hız kavramının adımını atmadığı pek çok alanda yaşamın normal akışı olarak anlaşılmaktadır. Günümüzde insanoğlu, hız kavramı adı altında yapıımış olan hataların geçte olsa farkına varabilmiş ve bu felsefeyi, henüz bozulmayıp tarihin tozlu sayfalarında yerini almamış olan gelenekler için bir kurtarıcı ve bir çözüm yolu olarak yorumlayıp benimsemiştir (Cittaslow, 2020).

Yavaş şehir hareketi, şehirlerin hangi alanlarda önemli ve özel olduklarının ortaya çıkarılmasını amaçlayan ve bu özellikleri koruyabilmek adına stratejilerin geliştirilmesini destekleyen bir akımdır. Şehre ait değerleri, müziği, sanatı ve dokuyu, bir uyum içinde, yaşayanlara ve ziyaretçilere zevk alabilecekleri bir hızda yansıtmayı hedeflemektedir. Geleneksel yemekleri, yerel zanaatları ve sanatları, sadece eskilerin hatırlayabileceği kavramlar olmaktan çıkararak gelecek nesiller ve ziyaretçilerle paylaşmayı amaçlayan bir harekettir. Geçmişten gelen değerlerin koruması ve geleceğe yansıtmaları hedeflenirken, aynı zamanda bu değişim, insana zararlı olmayan temiz ve yenilenebilir enerji kaynaklarının kullanımını teşvik ederek de yapılabilmektedir (Cittaslow, 2020). Bu yaklaşımlardaki esas amaç, iyi gıda, sürdürülebilir ekonomi, sağlıklı çevre ve toplu yaşam ritimlerine bağlı kalarak sağlam ve canlı bir gelişim sağlamaktır. Alında bu yönleriyle yaklaşım, şehirlerin gelecek nesiller adına sürdürülebilir kılınmasına da ciddi katkılar sağlamaktadır (Kazma, 2017). Yavaş şehir yaklaşımında, şehrin doğalını oluşturan ve yukarıda sayılan geleneksel değerlerin korunması ne kadar önemli ise, mevcuttaki doğal şehir sisteminin dışından gelen baskı ve şoklara karşı, şehrin direncini artırmak ve bu doğallığı sürdürülebilir kılmak da yavaş şehir sürecinin sürdürülebilirliği açısından o kadar önemli olacaktır.

\subsection{Yavaş Şehir Hareketi ve Yavaş Şehir Ağları}

Yavaş Şehir hareketi resmi olarak, 1999 yılında İtalya'da "Slow Food" akımının kurucusu olan Carlo Petrini ve kurucu şehirler olan Bra, Chianti, Orvieto ve Positano kentlerinin belediye başkanlarının "Yavaş Kent (cittaslow)" sözleşmesini imzalamasıyla doğmuştur. İtalyanca Citta (şehir) ve İngilizce Slow (yavaş/sakin) kelimelerinin birleştirilmiş hali olan Cittaslow, "Yavaş veya sakin şehir" anlamına gelmektedir (Cittaslow, 2020).

Yavaş şehir hareketinin ana merkezi, İtalya Orvieto kentindedir. Yavaş şehir olmak için aday olan şehirlerin değerlendirilmesi de bu merkezde yapılmaktadır. Merkez, faaliyetlerin ulusal çerçevelerde de ilerletilebilmesi için Ulusal Ağlar kurmuştur. Bu bağlamda, bir ülke içerisinde 3 adet kentin üye olması durumunda bu kentler bir araya gelerek kendi içlerinde ulusal ağlarını oluşturabilmektedir. Ulusal çapta oluşturulmuş olan bu ağ, birliğin ana yönetim organı olan Uluslararası Koordinasyon Komitesini temsil etmektedir. Ayrıca bu merkezle birlikte çalışan "Slow Food Editor" adlı bir yayınevi ve bir de Gastronomik Bilimler Üniversitesi (“University of Gastronomic Sciences”) kurulmuştur (Eskicioğlu, 2009).

Cittaslow, kendi toplumunun yaşam kalitesini arttırmayı hedeflemiş olan ve nüfusu 50.000'den fazla olmayan kentlerin başvurabileceği bir birliktir (Cittaslow, 2020). Üyeliğe başvuran aday kentlerin, tüm kaynaklarını ve yerel hammaddelerini koruyacağını, hazır gıdalara ve kültürel standardizasyona karşı geleceğini taahhüt eden kentler olması gerekmektedir (Cittaslow, 2020).

Dünya çapında kuruluşundan itibaren hızla gelişen Cittaslow ağında son güncel verilere göre; Avustralya, Avusturya, Belçika, Kanada, Çin, Kolombiya, Danimarka, Finlandiya, Fransa, Almanya, İngiltere, Macaristan, İzlanda, İrlanda, İtalya, Japonya, Hollanda, Yeni 
Zelanda, Norveç, Poland, Portekiz, Rusya, Güney Afrika, Güney Kore, İspanya, İsveç, İsviçre, Tayvan, Türkiye, Kuzey Kıbrıs Türk Cumhuriyeti ve ABD olmak üzere 30 ülkeden 252 şehir bulunmaktadır (Cittaslow, 2020). Günümüzde, Türkiye'den de bu harekete dahil olan yavaş şehir sayısı; 2019 yılında ulusal ağa katılan Köyceğiz ve Ahlat'la beraber, Akyaka, Gökçeada, Halfeti, Perşembe, Şavşat, Seferihisar, Taraklı, Uzundere, Vize, Yalvaç, Yenipazar, Eğirdir, Gerze, Göynük ve Mudurnu şehirleri olmak üzeri 17’ye ulaşmıştır (Cittaslow Turkiye, 2020).

\subsection{Türkiye'nin Yavaş Şehir Başkenti Seferihisar}

Seferihisar'ın Yavaş Şehir çalışmalarına, 2009 yılının yaz aylarında Belediye Başkanı Tunç Soyer tarafından başlanılmış ve adaylığa başvurulmuştur (Cittaslow Türkiye, 2020). Seferihisar, yavaş şehir kriterleri bağlamında bir değerlendirmeye tabi tutulduğunda; Çevre politikalarında $\% 83.33$, tarımsal, turistik, esnaf ve sanatkarlara dair politikalarında $\% 90$, misafirperverlik, farkındalık ve eğitim için yapılan planlar üzerinden değerlendirildiğinde, \% 90 , sosyal uyum politikalarında, $\% 70$ ve ortaklıklarla ilgili politikalarında ise $\% 100$ oranında belirtilen şartları karşıladığı görülmüş ve Türkiye'nin ilk yavaş şehri olmaya hak kazanmıştır (Aydoğan, 2015). Böylece, adaylık sürecinde hazırlanmış olan sunum dosyaları ve kararlılıkları ile Seferihisar, 29 Kasım 2009'da resmi olarak Cittaslow Birliğine üye olarak kabul edilmiş ve Türkiye'nin Cittaslow Başkenti olmuştur (Cittaslow Türkiye, 2020). Seferihisar'ın, ilk yavaş şehrimiz olması ve İzmir'in ilçesi olması, bu çalışmada örnek uygulama alanı olarak seçilmesinde etkin olmuş ve çalışmadaki tüm uygulamalar Seferihisar örneğinde yürütülmüştür.

\section{YAVAŞ ŞEHIR KRITERLERI}

Kuruluşundan itibaren kısa sürede dünya çapında kabul görüp hızla yaygınlaşan Yavaş Şehir akımı başlangıçta 59 maddelik bir kriterler listesine sahipken, 2013 yılında Uluslararası Bilim Komitesi tarafından yapılan çalışmalar neticesinde bu liste güncellenmiş ve madde adeti 72'ye çıkarılmıştır (Cittaslow, 2020). 72 maddeden oluşan bu liste içerisinde; yemekten zevk almak, geleneksel sofraları arttırmak ve eşi benzeri olmayan yöresel ve kaliteli olan gıdaları desteklemek gibi konuların yanı sıra, ayrıca, kent tasarımı ve planlaması, çevrenin korunması, ağaçlar dikilerek daha fazla yeşil alan oluşturulması, bisiklet ve yaya yollarının düzenlenerek arttırılması, ışıklı panoların kaldırılması, otomobillerde güvenlik için kullanılan alarm sistemlerinin yasaklanması, ışık, gürültü ve hava kirliliği yaratacak durumların engellenmesi, sürdürülebilir alternatif enerjilerin kullanılması, toplu taşımaların geliştirilmesi ve yeni yapılacak olan yapılarda çevreye dost sürdürülebilir bir mimarinin benimsenmesi gibi konular bulunmaktadır (Cittaslow, 2020).

Toplam 72 maddenin oluşan yavaş şehir kriterleri içerisinde çalışmanın odaklandığı konu olan bisiklet kullanımı ve bisiklet yolları ile ilgili olabileceği düşünülen yavaş şehir kriterleri ise, aşağıdaki gibi sıralanabilir (Cittaslow Türkiye, 2017);

Çevre politikaları ile ilgli kriterler;

- Hava kalitesinin yasa tarafından belirlenen parametrelere uygunluğunun belgelenmesi,

- Su kalitesinin yasa tarafından belirlenen paramterlere uygunluğunun belgelenmesi,

- Görsel ve gürültü kirliliğinin kontrol altına alınması ve azaltılması,

- Kent aydınlatma sistemlerinin programlanması ve gereksiz ışık kirliliğinin azaltılması,

- Biyoçeşitliliğin korunması.

- Altyapı politikaları ile ilgli kriterler;

- Kamu binalarına bağlı bisiklet yollarının sağlanması, 
- Mevcutta bulunan bisiklet yollarının araç yolları ile kilometre üzerinden karşılaştırılması,

- Otobüs, hızlı tren gibi toplu taşıma araçlarının aktarma merkezlerinde bisiklet park yerlerin sağlanması,

- Kişisel taşıt kullanımına alternatif olarak eko-ulaşım planlanması,

- Kent merkezlerindeki malların sürdürülebilir bir biçimde dağıtımının sağlanması.

- Kentsel yaşam kalitesi politikası ile ilgli kriterler;

- Kentin sürdürülebilir direncinin korunması için planlamalar yapılması,

- Kent içerisindeki kamusal binaların, kent merkezlerinin ve kente ait değerlerin iyileştirilesi ve değerinin arttırılması için program ve projeler geliştirilmesi,

- Kentsel yaşanılabilirliğin sağlanması için çalışmaların yapılması,

- Kentte bulunan marjinal alanların yeniden değerlendirilerek kullanıma açılması,

- Bilgi ve iletişim sektörlerindeki gelişimlerden yararlanılarak turistlerin ve vatandaşların interaktif hizmetlerden faydalanmasının sağlanması,

- Sürdürülebilir mimari alanlarının geliştirilmesi için hizmet masası oluşturulması,

- Kentte kablosuz internet sistemlerinin kurulması,

- Kenti kirleten durumların izlenmesi ve azaltıması,

- Sosyal altyapıların desteklenmesi,

- Kamusal sürdürülebilir planlamanın desteklenmesi,

- Misafirperverlik, farkındalık ve eğitim ile ilgili kriterler;

- Yavaş güzergahların basılı olarak veya internet üzerinden erişilebilir olması,

- Yavaş şehir içerisindeki önemli yönetimsel kararlara tabandan tavana kadar kent sakinlerinin katılımını sağlayacak tekniklerin üretilmesi,

- Obezite diyabet gibi sorunlara karşılık sağlık eğitimlerinin sağlanması,

- Halka Cittaslow'un anlamı hakkında sistematik ve kalıcı eğitimlerin verilmesi,

- Cittaslow üzerine çalışan yerel derneklerin aktifliğinin korunması,

- Cittaslow kampanyalarının desteklenmesi,

- Cittaslow'a ait salyangoz logosunun internet sayfası üzerinde ve antetli kağıtlar üzerinde kullanılması (Şekil 1).

- Sosyal uyum ile ilgli kriterler;

- Genç nüfusun istihdam durumu,

- Yoksulluğa karşı çalışmaların yürütülmesi,

- Toplumsal ortaklıkların ve sivil toplum örgütlerinin oluşturulması,

- Gençlerin faaliyette olabileceği alanların ve gençlik merkezlerinin oluşturulması.

- Ortaklıklar ile ilgli kriterler;

- Gelişmekte olan ülkelerde Slowfood ve Cittaslow akımlarının yayılmasını sağlayacak şekilde geliştirmelerin desteklenmesi ve işbirliklerinin yapılması.

\section{YAVAŞ ŞEHIR KAPSAMINDAKI BISIKLET DOSTU ŞEHIR YAKLAŞIMININ ŞEHRIN DAYANIKLIĞI (DİRENÇLİLIĞi) AÇISINDAN ŞEHRE (YEREL KALKINMAYA VE TURIZME) ETKISi}

Burada, "bisiklet dostu şehir yaklaşımı" ifadesi (turistik ve sportif potansiyele sahip olmakla birlikte) ile, bir çevre dostu ulaşım aracı olan bisikletin kullanımını özendirme ve arttırma amacıyla gerekli tedbirleri alarak çalışmalar yapan, stratejiler belirleyen ve bu konuda uygulamaları olan şehirler kasdedilmektedir.

20. ve 21. yüzyılın önümüze koyduğu ve en azından kullanım noktasında insanoğlunun vazgeçilemezi haline gelen teknolojik ürünler ve bunların doğal çevremiz ürerinde neden olduğu yan etkiler, aslında alternatif turizm açışından farklı fırsatlar da doğurmaktadır. Yavaş şehir hareketine de bu noktadan yaklaşıldığında, çağın genel yaşam trendine alternatif 
doğalın ve sahip olunanın öncelenmesi; yeni bir yaşam tarzı ile seçeneği, turizm hareketliliği ve turist grubu oluşturmuştur denilebilir. Yerel ekonomiyi canlandırma açısından, gerek turizm gerekse de yerel odaklı olarak ortaya çıkan ve sürdürülebilir kalkınmayı önceleyen bu ve benzer hareketler ve bunların değişik alternatifleri günümüzde pek çok araştırmanın ilgi noktası olmuş ve bu çalışmaların sosyal etkileri de yine literatürde değişik araştırmalara konu oluşturmuş ve oluşturmaya da devam edecek gözükmektedir (Tao \& Wall, 2009). Özellikle kırsal alan veya taşra turizmi denilebilecek bunun gibi yeni eğilimlerin veya küçük yerleşim alanlarının kalkınmasına yönelik bu tür yaklaşımların, turizmin veya kalkınmanın tüm gelişim alanlarında ölçülebilir ve etkin bir şekilde hesaba katılması ve hatta, özellikle turizm sektöründe ve küçük yerleşim alanlarının kalkınmasında en büyük meydan okumayı oluşturacak olan iklim değişikliğinin etkisinin azaltılması yönündeki sürekli artan baskının oluşturduğu gereksinimlerin de ayrıca dikkate alınması; bu tür şehirlerde çevre dostu sürdürülebilir bir kalkınma ve turizm anlayışının gelişimine ve dolayısıyla da şehirlerimizin dirençliliğine olumlu katkı sağlayacaktır (Peeters, Gössling, \& Becken, 2006). Bu noktada, kaynaklarımızı tüketen, kaynak yoğun ve kirletici turizm ve kalkınma çeşitlerinden, böylesi sürdürülebilir bir kalkınma ve turizm biçimine geçiş için, gerek mevcut gerekse de yeni oluşan potansiyel pazarın, çevreye etkisi düşük ve yine düşük karbon etkili yeni ürünlerin geliştirilmesine duyduğu gereksinim; çok açık olup bu tür yaklaşımların farklı ve cesaretlendirici bir boyutu olarak karşımızda durmaktadır (Simpson, Gössling, Scott, Hall, \& Gladin, 2008).

Gerek çalışma alanı olarak Seferihisar'ın ve gerekse de ilçenin bir parçası olduğu Ege bölgesinin, üretken bir bölge olması ve yine gerek bölge içi, gerek bölgeler arası ve hatta ülkeler arası insan ve ürün hareketliliği açısından kara, hava ve deniz ulaşım olanaklarının tümüne sahip yoğun hareketliliklerin olduğu bir bölge olması, gerek bölgeyi gerekse de Seferihisar'ı bu yaklaşımlar noktasında önemli bir potansiyel lokasyon haline getirmektedir. Bu kapsamda şehirde gerçekleştirilen ve gerçekleştirilecek olan, doğa dostu sürdürülebilirliği ve dirençliliği hedefleyen, örneğin bisiklet sürmeyi, yürümeyi ve engellileri önceleyen çözümler; gerek bu günü yaşama ve gerekse de yarını yaşatma adına atılmış en etkin adımlar olacaklardır (European Commission's General Directorate of Tourism, 2011).

Bu çalışmanın da odak noktasını oluşturan bisiklet örneği üzerinden konuya devam edecek olursak, gerekli önlemler ve bundan daha önemlisi gerekli çalışmalar, atraksiyon ve özendirici faaliyetlerle bisiklet kullanımının şehirde yaygınlaştırıması ve bisiklet güzergahlarının, şehir sakinlerinin ve turistlerin gereksinim ve beklentilerini karşılayacak şekilde ve çağın gerektirdiği biçimde etkin ve verimli bir hale getirilmesi; gerek çevresel, gerek ekonomik ve gerekse de sosyo-kültürel açıdan sürdürülebilir bir turizm ve kalkınma örneği oluşturacaktır.

Yerel ulaşımda bisiklet kullanımı, çevresel etkisi de neredeyse hiç olmayan en ideal ve yavaş olmasıyla da yavaş şehir yaklaşımına en çok uyan ulaşım şekli olarak karşımıza çıkmaktadır. Ayrıca, yavaş içeriğinden dolayı, farklı ülkeler ve bölgelerdeki kültürel ve doğal değerlerle entegre değişik yansıma ve yankılar bulmanın yanı sıra, toplumsal yaşam tarzlarına karşı ciddi bir ilgi oluşturma potansiyeline de sahip gözükmektedir. Böyle bir uygulama, yerel ekonomiye önemli bir katkı sağlayacağı gibi, yöresel sürdürülebilir kalkınma modelinde de etkin bir yere sahip olacaktır. Sürdürülebilir bisiklet kullanımı, küresel politikalar içerisinde sürdürülebilir ekonomik gelişme için bir şans olarak değerlendirilmektedir (UNWTO-UNEPWMO, 2008). Bu konuda gerçekleştirilen uygulamalar, yerel bisiklet kulanım politikasının, yerel toplumlar için önemli bir ekonomik kaynak oluşturduğunu göstermektedir (Cope, Doxford, \& Hill, 1998; Ritchie \& Hall, 1999).

Turizm açısından değerlendirildiğinde, yaklaşımın; diğer turizm tarzlarından çok daha fazla, destinasyondaki çevreyi, kültürü ve insanları tanıma olanağı sağlamasının yanı sıra, en 
uygun ulaşım tarzı olan bisiklet kullanımını tercih eden ve uzun kalan bisikletçi turist davranışı olanağını da sunan bir turizm şekli ortaya koyduğu görülmektedir (Ritchie \& Hall, 1999). Diğer taraftan, bisiklet kullanıcısı turistlerin gittikleri ve konakladıkları yerlerdeki mevcut kaynakları ve altyapıyı kullanmaları da, bu tür turizmi tercih eden turistlerin genel davranışı olarak gözlemlenmektedir. Bu turistlerin şehre çekilmesi amaçlanıyorsa, destinasyona ulaşım maliyetlerini minimuma indirecek çözümlerin üretilmesi oldukça önemlidir (EcoGIS Consultants, 2000). O nedenle, bu tür turizmin potansiyel turist grupları olan bisiklet kullanıcısı turistler ile oluşturdukları grup ve toplulukların çok iyi analiz edilip tespit edilmesi, şehrin ve bölgenin bisiklet kullanım potansiyelinin bu tür turizmin gereksinimlerine ne oranda cevap verebildiğinin ortaya konması, oluşan ve muhtemel eksikliklerin hızla belirlenerek giderilmesi ve şehrin bu yönden cazip hale getirilmesi için de gerekli olan tüm girişimlerin tez elden gerçekleştirilmesi önemlidir.

\section{CBS'NIN YAVAŞ ŞEHIR, DAYANIKLILIK VE SÜRDÜRÜLEBILIRLIK GIBi KENTSEL YAKLAŞIMLAR AÇISINDAN ÖNEMI}

Dünya gündeminde sürdürülebilir kent yönetimi konusunda CBS; sahip olduğu özellikler itibarıyla, kentsel ve bölgesel planlama, tarım, orman, peyzaj planlama, jeoloji, savunma, güvenlik, turizm, arkeoloji, yerel yönetimler, nüfus, eğitim, çevre, tıp gibi birçok sektörde oldukça geniş bir yelpazede pek çok uygulama olanağı ortaya koymaktadır (Kaya Bensghir \& Akay, 2006). Bu bağlamda günümüzde, CBS destekli kent yönetim sistemleri; kentlerin yönetiminde sürdürülebilir planlamanın intiyaç duyulduğu hemen hemen her alanda etkin, modern, çağdaş ve en önemlisi de çok kriterli analizlerle üretilen güvenirliği yüksek çözümleri üreten, bilgiye dayanan ve bu nedenle de verimliliği yüksek bir yönetim-bilişim ve karar destek sistemi konumuna oturmuş bulunmaktadır. Günümüzde ve gelecekte, şehirlerin etkin, yetkin ve sürdürülebilir bir yönetime sahip olmaları, ancak bu tür sistemlerin desteğiyle mümkün olacak ve bu sistemler, kentlerin çağdaşlık seviyelerini ölçmede de bir tür barometre vazifesi göreceklerdir.

Yavaş Şehir yaklaşımındaki, hızı olmanın karşısında olma, aslında yavaş olmak değil de, bir işin doğru, planlı ve geleceğe zarar vermeyecek biçimde yapılması anlamına gelmektedir ve kısacası bu yaklaşımın temelinde sürdürülebilirlik vardır (Kazma, 2017). Yavaş Şehir yaklaşımında CBS, tam da bu konularda ortaya koyduğu yetenekleri ile ön plana çıkar. Bu yöntem ile kentlerin gelecek planlarında, kent içi durumlar hakkında bilgi sahibi olunabildiği gibi ön kestirimler yaparak, gelecekte uygulanması düşünülen planlamalarda verilebilecek yanlış kararların ve dönüşü mümkün olmayacak sonuçların, çeşitli analizler ve kontroller ile fark edilebilmesi de mümkün olabilmektedir. Bu da CBS'yi, sürdürülebilirlik, optimizasyon ve çok kriterli analizlerin vazgeçilmez aracı haline getirmektedir. Bu tür bilgi sistemleri ile yürütülen sürdürülebilirlik analizleri ve uzun zaman gerektiren karar alma çalışmaları daha az emek harcayarak, daha hızlı bir biçimde yüksek doğruluk ve güvenirlikle yapılabilmektedir. $\mathrm{Bu}$ da, her türlü kaynak maliyetini minimize edip kaynak israfını önlemek, yönetimi sürdürülebilir kılmak ve verilen yönetimsel kararların etkinliğini en üst seviyeye çıkarabilmek anlamına gelmektedir. CBS'nin bütün bu özellikleri, çalışmanın konusu olan ve yavaş şehir kriterleri açısından da önemli olan bisiklet dostu bir şehirde, şehrin gerek sürdürülebilirliği ve gerekse de dirençliliği açısından yapılması gereken çoklu kriter analizlerinde optimum sonuçlara ulaşmada CBS kullanımını; tek ve en etkin teknik çözüm haline getirmektedir.

\subsection{KENTSEL EKO-DAYANIKLILIK VE SÜRÜRÜLEBILIRLIK AÇISINDAN CBS ORTAMINDA DEĞERLENDIRILEBİLECEK YAVAŞ ŞEHIR KRITERLERi}

Çevresel sürdürülebilirlik ve dolayısıyla şehrin bu yöndeki dirençliliğinin ortaya konması bağlamında, Seferihisar mevcut bisiklet yol ve güzergahlarının ilgili yavaş şehir kriterleri baz alınarak CBS ortamında gerçekleştirilecek analizleri ile CBS; bu kriterler bağlamında mevcut 
durumların tespiti, uyumluluk analizleri ve kontrollerin sağlanması gibi işlemler ile proje geliştirme aşamalarından karar alma ve proje uygulama aşamalarına kadar proje sürecinin tüm aşamalarında, hatta proje sonrası izleme süreçlerinde de kriterlere maksimum seviyede uygunluğun sağlanmasında en etkin sonuçları üretme yeteneğine sahip yegâne teknolojidir. Ayrıca, buradan hareketle, konum tabanlı bir karar ve bilişim-yönetim destek sitemi olarak CBS'nin, Yavaş Şehir üyelik kriterlerinin değerlendirmesinde de yine en güçlü sistem olarak önerilebileceği, hatta Yavaş Şehir yönetim-bilişim biriminin merkezine oturabilecek potansiyelde kabiliyetlere sahip bir sistem ve teknoloji olarak karşımızda durduğu da vurgulanabilir.

Çevresel açıdan gerek şehrin sürdürülebilirliği ve gerekse de dayanıklıı̆ı bağlamında Yavaş Şehir kriterleri arasında yer alan bisiklet yol ve güzergahları ile ilgili kriterler doğrultusunda CBS ortamında yapılabilecek çalışmalardan bazıları aşağıdakiler gibi sırlanabilir (Kazma, 2017, s. 87-90);

- Hava temizliğinin kontrolü sağlanarak, hava kirliliğini tetikleyebilecek durumların önceden farkına varılabilmesinde ve kontrol altına alınabilmesinde kullanılabilecektir. Kirletici araçlarla ulaşıma alternatif çevre dostu bisiklet kullanımının yaygınlaştırııması ile CBS ortamında öncesi ve sonrası durum analizleri ile iyileşme ortaya konabilecektir.

- Trafiğe ve gürültü kirliliğine sebep olan durumların, CBS ortamında yapılacak analizler ile bisiklet kullanımını içeren çözümlerin nasıl bir sonuç oluşturduğu ve oluşturacağının ortaya konmasında yada bazı öngörülerin ortaya çıkarılmasında kullanılabilecektir.

- Enerji tasarrufu ile ilgili yapılacak çalışmalarda, alınacak kararların doğruluğunun denetlenmesi ve alternatif seçeneklerin sunulmasına olanak verebilecektir. (Örneğin fosil yakıtlara duyulan gereksinim düşürülebilecek ve yine fosil yakıtlı araçlara elternatif olarak sunulan pahalı elektrikli araç yerine çok daha ucuz elektrikli bisiklet kullanımı yaygınlaştıılabilecektir. Öyleki, normal bisikletlerin elektrikli bisiklete dönüşümü günümüzde hem ucuz hem de oldukça basit olduğundan bu dönüşüm kolayca sağlanabilir. Hatta, bu, yerel halk için yeni bir gelir kaynağı oluşturma potansiyeline sahip bir çözüm olarak da düşünülebilir.)

- Biyoçeşitliliğin korunmasında, mevcut alan üzerindeki yapılaşmalar araştırılarak denetimi sağlanabilecektir. Bisiklet kullanımının yaygınlaştırılması bu açıdan da önemli bir katkı sağlayacaktır.

- Yavaş Şehir altyapı politikaları dahilinde bulunan bisiklet yolları ile ilgili analizler sayesinde uygunluk denetimleri yapılabilecektir.

- Sağlık hizmetlerine hanelerin ulaşımı ve yakınlığı analiz edilerek, kapasite yeterliliği denetlenebilecektir. Bu sağlık kuruluş ve hizmetlerine bisikletle ulaşım analizleri yine CBS ortamında yapılabilecektir.

- Marjinal alanların kullanımı, mevcut yeşil alanların iyileştirilmesi ve oluşturulması, geleceğe dönük yapılacak olan ilgili planlamaların kontrollü biçimde geliştirilmesine olanak sağlayabilecektir. Bisiklet kullanılarak bu alanlara ulaşım ve buraların bisiklet kullanımı için uygun donatılarla donatıması gibi pek çok analiz gene CBS ortamında yapılabilecektir.

- Kırsal bölgelerde yaşayanların, sosyal donatılara ulaşımının ne derece sağlandığı kontrol edilebilecek ve köyleri geliştirici projelerde uygun yer seçimine yardımcı araç olarak kullanılabilecektir. Bu gibi kriterlerde özellikle elektrikli bisiklet yaklaşımı ile analizler yapılabilir.

- Kültürel ve turistik mekanlara ulaşımların analizi denetlenebilecek ve bu mekanların çevresinde bulunan otellerin kapasitelerinin incelenerek yeterlilik durumu kontrol edilebilecektir. $\mathrm{Bu}$ kritede de bisiklet dostu turizm ve bisiklet dostu turist gereksinimlerini karşılama bağlamında analizler yine CBS ortamında 
gerçekleştirilebilecektir.

- Tarıma elverişli alanların imar planları ile mevcut durum analizleri yapılarak, yeni yapılaşmaların yer seçimleri denetlenebilecektir. Yeni yapılaşmalarda da yine bisiklet yolu altyapısı mutlaka düşünülmeli ve CBS'den de yardım alınarak planlanmalıdır.

- Oluşturulması gereken yavaş güzergahlar için, seçilen yolların yürüyüş veya bisiklet yolu olarak kullanımına uygunluğu kontrol edilebilecek ve alternatif yollar üretilebilecektir.

- Obezite, diyabet vb. sorunlara yönelik kent içi mevcut durum analizleri yapılarak çevre faktörleri incelenebilecektir. Kentin en çok hangi bölgeleri bu gibi durumlardan etkilenmekte ise 0 bölgeler tespit edilerek özel çalışmaların yapılması sağlanabilecektir. Yine bu kriterde geçen sorunun çözümünde de bisiklet kullanımının yaygınlaştırılmasına yönelik CBS analizleri ve bu analizler sonucunda gerçekleştirilecek çalışmalar etkin olabilecektir.

- Özel taşıt kullanımına alternatif olarak, eko ulaşım planlamaları düzenlenebilecektir. Bu planlamaların CBS ortamında normal ve elektrikli bisiklet bağalmındaki analizleri eko ulaşım için son derece değerli olacaktır.

- Kent içerisindeki malların sürdürülebilir bir biçimde dağıtılabilmesi için uygun güzergahlar belirlenebilecektir. Bu amaçlarla da yine normal, özellikle de üç tekerli modern elektrikli bisiklet kullanımının yaygınlaştırıması düşünülebilir.

- Kamu binalarına bağlanan bisiklet yolları denetlenebilecek, yok ise alternatif çözümler geliştirilebilecektir.

- Bölge halkının sosyal hizmetlere ulaşımı ve yeterlilikleri kontrol edilebilecektir.

- Yavaş Şehir eğitimlerine ve merkezlerine halkın katılımı ve erişimi değerlendirilebilecektir.

- Genç neslin istihdam durumunun kontrol altına alınmasında kullanılabilecektir.

- Engellilerin şehre entegrasyonunun sağlanması çalışmaları ve kontrolleri yapılabilecektir.

- Belediyelerin kamu konut yatırımı için seçeceği bölgelerin kent içi donatılara ve ulaşımlara uygunluğu kontrol edilebilecektir.

- Yoksulluk seviyesi tespit edilebilir, hangi bölgelerde yoksul kesimlerin bulunduğu belirlenerek gelecekte yapılacak çalışmalar ve yatırımlar için uygun yer seçimi sağlanabilecektir.

- Yavaş Şehir kapsamında yapılacak aktivitelerin ve kampanyaların kent içerisindeki dağılımı kontrol edilerek, halkın bu aktivitelere katıımı kontrol edilebilecektir.

Bütün bu yavaş şehir bisiklet kullanımı ilintili kriterler kapsamında gerçekleştirilecek CBS analizleri, nihai olarak şehrin çevresel sürdürülebilirliği ve dirençliliği açısından da son derece önemli sonuçlar ve çözümler içerecektir.

$\mathrm{Bu}$ aşamada şunun da vurgulansı yerinde olacaktır; aşağıda verilen ve bu çalışma kapsamında yapılan tüm CBS analizleri, bir önceği paragrafda bahsedilen bakış açısıyla yavaş şehir bisiklet yol ve güzergah kriterleri dikkate alınarak gerçekleştirilmiştir. 


\section{SEFERIHISAR BISIKLET YOLLARININ YAVAŞ ŞEHIR KRITERLERINE GÖRE CBS ORTAMINDA DEĞERLENDIRILMESI}

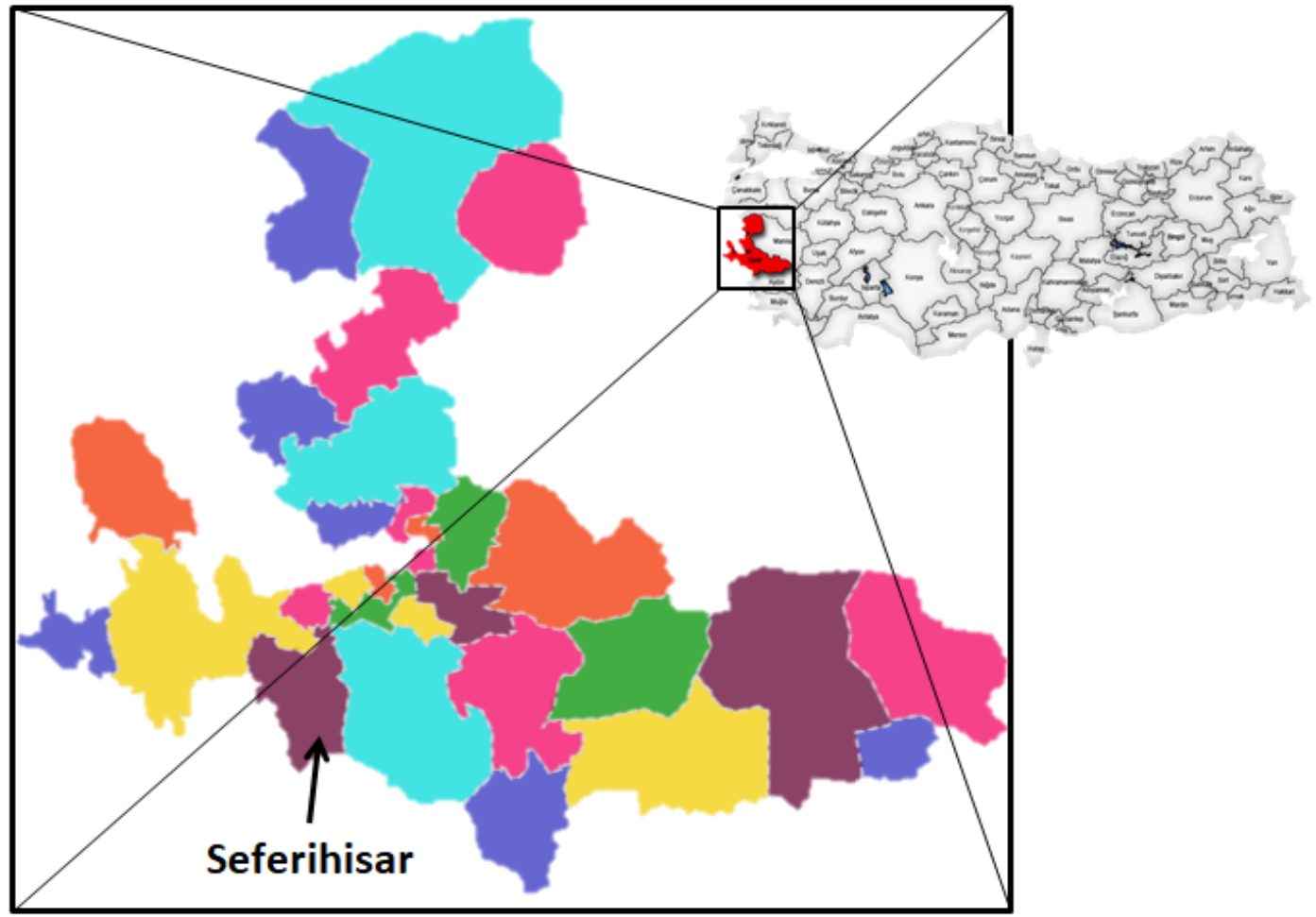

Şekil 2. İzmir ili, ilçeleri ve Seferihisar'ın bölgesel konumu

Bu çalışma, Türkiye'nin ilk yavaş şehri olan İzmir ili Seferihisar ilçesi (Şekil 2) için yukarıda bahsedilen amaçlar doğrultusunda ve yine yukarıda verilen analiz konseplerinden biri dikkate alınarak mevcut bisiklet yolları için CBS ortamında gerçekleştirilen kriter analizlerini içermektedir. Çalışma kapsamında gerçekleştirilen konuyla ilgili bu analizler ise aşağıdaki şekilde özetlenebilir;

Seferihisar ilçesindeki mevcut bisiklet yol ve güzergahları kapsamında,

- yeşil alanlarla olan ilişkiyi veren,

- su kitleleri ile olan ilişkiyi veren,

- eğim ve yol konforu ilişkisini veren,

- kamu binalarına bağlı verimli bisiklet yolları ilişkisini veren,

- aydınlatma ile olan ilişkiyi veren,

- mevcut binaların bisiklet yollarına ulaşım ilişkisini veren,

- kamu binalarına ulaşım ilişkisini veren ve

- yavaş güzergahların oluşturulmasını veren analizler yapılmıştır.

Araştırma bölgesi olarak kabul edilmiş olan Seferihisar kentinin sürdürülebilirliği ve dirençliliği açısından bisiklet yol ve güzergahları ile ilişkili yavaş şehir kriterlerinin CBS ortamında değerlendirilmesinde kullanılan veriler ile nasıl ve nereden elde edildikleri aşağıda belirtilmiştir (Kazma, 2017, s. 92-93).

- Araştırma bölgesi içerisinde bulunan konutlar, yollar, belirlenmiş yerleşim alanları, aydınlatma direkleri projeleri, tarım alanları ve su yüzeyleri Seferihisar Belediyesinden 
elde edilmiştir.

- Bölge içerisinde bulunan sosyal ve kamusal donatılar Google Earth'te koordinatları tespit edilerek konumsal veri ile irtibatlı hale getirilmişlerdir.

- Bisiklet yolları, İzmir Büyükşehir Belediyesi tarafından hazırlanmış olan "Antik Liman - Teos - Sığacık" yürüme ve bisiklet yolu projesinden ve "Seferihisar - Orhanlı Gödence - Seferihisar" yürüme ve bisiklet yolu projesinden elde edilmiştir.

- Ormanlık alanlar, Google Earth üzerinden karşılaştırılarak projelendirilmiştir.

- Bölgeye ait demografik veriler, Türkiye İstatistik Kurumu'ndan elde edilmiştir.

- Biyoçeşitlilik haritası, Avrupa Çevre Ajansı tarafından hazırlanmış olan Biyoçeşitlilik haritasından alınmıştır.

- Eğim verileri, Amerika Birleşik Devletler Jeoloji Araştırma Organizasyonu'nun hazırlanmış olduğu Dünya Eğim Haritası'ndan elde edilmiştir.

\subsection{Yavaş Şehir Seferihisar Bisiklet yollarının CBS ortamında gerçekleştirilen analizleri}

Bu analizlerle, şehrin sürüdürülebililiği ve dirençliliği açısından yavaş şehir kriterlerine göre mevcut bisiklet yolu ve güzergahlarının uygunluk analizleri yapılarak, ilçe sınırları içerisinde bulunan bisiklet yollarının ilgili kriterler bağlamında yeterliliğinin kontrol edilmesi amaçlanmıştır. Bisiklet yollarının değerlendirilmesinde, yavaş şehir kriterlerinde yer alan; aydınlatma, ormanlık ve yeşil alanlara, su kıyılarına yakınlık, kamusal alanlar ile olan ilişkileri ve bu yolların eğim konforuna dair uygunlukları araştırılmıştır.

Seferihisar sınırları içerisinde 2 adet yavaş güzergâh olarak kabul edilmiş bisiklet yolu bulunmaktadır. Bunlardan ilki Antik Liman-Teos-Sığacık güzergâhı, diğeri ise SeferihisarOrhanlı-Gödence-Seferihisar döngüsü olarak planlanmıştır. Antik Liman istikametinde yer alan bisiklet yolunun toplam uzunluğu yaklaşık 3.7 kilometredir. Bisiklet yolu sırasıyla Sığacık Limanından başlayarak, Teos Kamp Alanı, Teos Gymnasium, Teos Akropol, Teos Helenistik Tiyatrosu, Teos Antik Kenti, Teos Meclis Binası ve Teos Agorası üzerinden geçerek Teos Liman Kamp Alanına ulaşmaktadır (Şekil 3). Diğer yavaş güzergah olan bisiklet yolu ise 88.6 kilometre uzunlukta ve Seferihisar ilçesinin kuzey batısında Urla yakınlarından ilçe sınırının dışına çıkarak, kuzey doğu Çamtepe yakınlarında tekrar ilçe sınırlarına girmektedir (Şekil 3). 


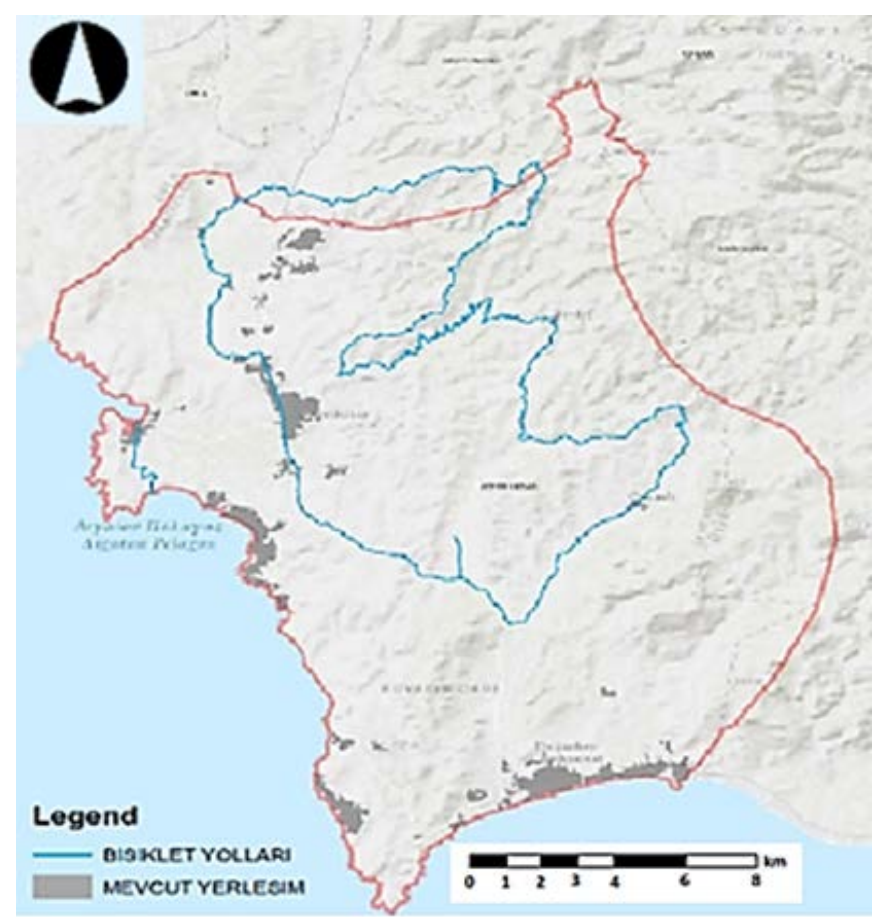

Şekil 3. İzmir, Seferihisar ilçesi mevcut bisiklet yolları (Kazma, 2017, s. 94).

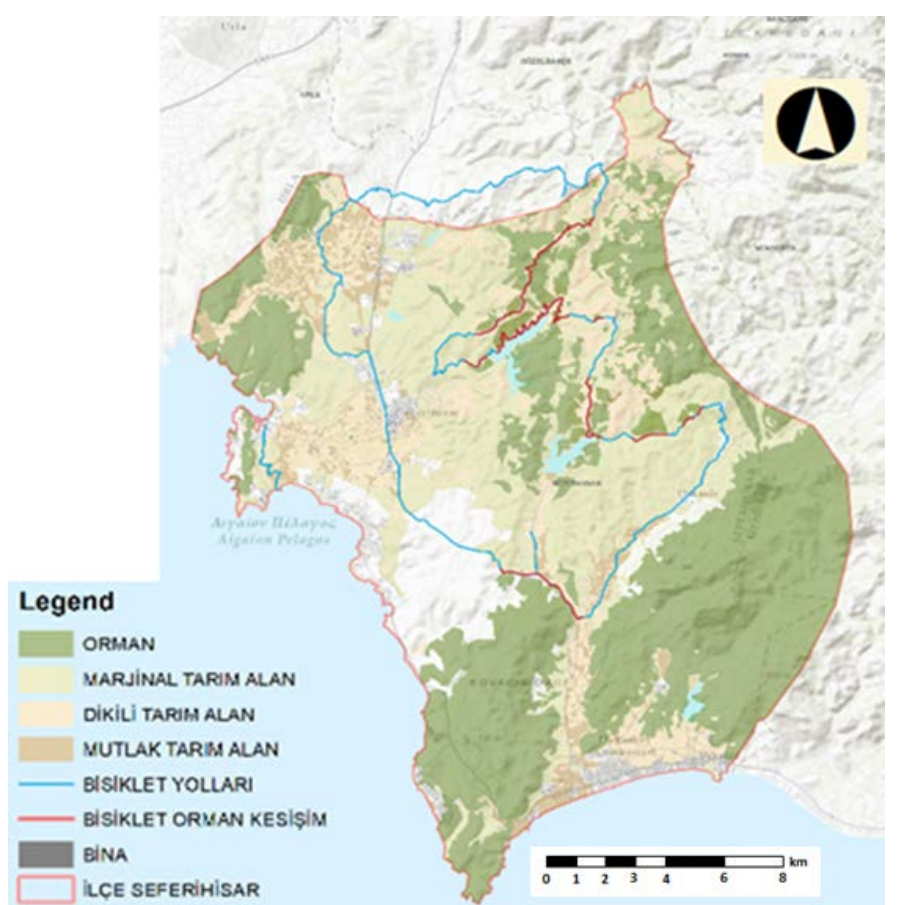

Şekil 4. Mevcut bisiklet yollarının ormanlık alanlar ile ilişkisi (Kazma, 2017, s. 95).

Toplam bisiklet yollarının yaklaşık \%4'üne denk gelen ilk güzergahta, yol boyunca orman alanları ile bir ilişki kurulmamakta yalnızca mutlak tarım, marjinal tarım ve dikili tarım alanlarının arasından geçilmektedir. Diğer güzergah üzerinde ise, tarihi dokunun gözlemlenebildiği herhangi bir yer bulunmamaktadır. Ancak, yol uzunluğunun yaklaşık \%28.3'ü boyunca ormanlık alanlardan, geriye kalan alanlarda ise Seferihisar merkezi haricinde kentsel yapıdan uzak tarım alanları ve çimlik alanlardan geçmesi ile daha doğa ile iç içe geçmiş bir bisiklet güzergahı olduğu anlaşılmaktadır (Şekil 4). Güzergahın, 
Seferihisar'ın köyleri üzerinden geçirilmesi ile yöresel kültürün tanıtımının ve köylünün desteklenmesinin amaçlandığı anlaşılmaktadır. Kırsal kesimlerde oturan nüfusa destek olarak üretici pazarlarının kurulması ve köylerde köylülerin kendi evlerini pansiyon olarak kiralamalarına izin verilmesi, Yavaş Şehir kapsamında kırsal kesimlere yapılan destekleyici projelere örnek olarak verilebilir. Bu şekilde yöresel kalkınmaya çevreci bir dokunuşla katkı sağlanmaya çalışıldığı görülmektedir. Bunun da yörenin sürüdürülebilir çevre bağlamında dirençliliğine olumlu bir etkisi olacağı düşünülebilir.

Diğer taraftan, CBS ortamında, bisiklet yollarının su kaynakları ile olan ilişkisi analiz edildiğinde ise, kısa güzergahın bu kaynakların yakınından hiç geçmediği diğer güzergahta ise sadece iki noktada ve \%7.1'lik bir oranla böyle bir bağlantının oluştuğu gözlemlenmiştir (Şekil 5b). Mevcut bisiklet yollarının su kitlesi ile ilişkisinin yetersiz kaldığı ve yukarıdaki çevreci dokunuşun en azından bu açıdan iyileştirilmesi gerektiği ifade edilebilir.

Bisiklet yollarının eğimli alanlardan geçişi üzerine yapılmış olan analizlerde toplam bisiklet yollarının \%40.5'inin \%5'lik eğime sahip olduğu ortaya çıkmaktadır. \%5'lik bu eğimin, genelde bisiklet yollarının yerleşim alanlarının dışında kaldığı durumların da gözlemlendiği ifade edilebilir (Şekil 5a).

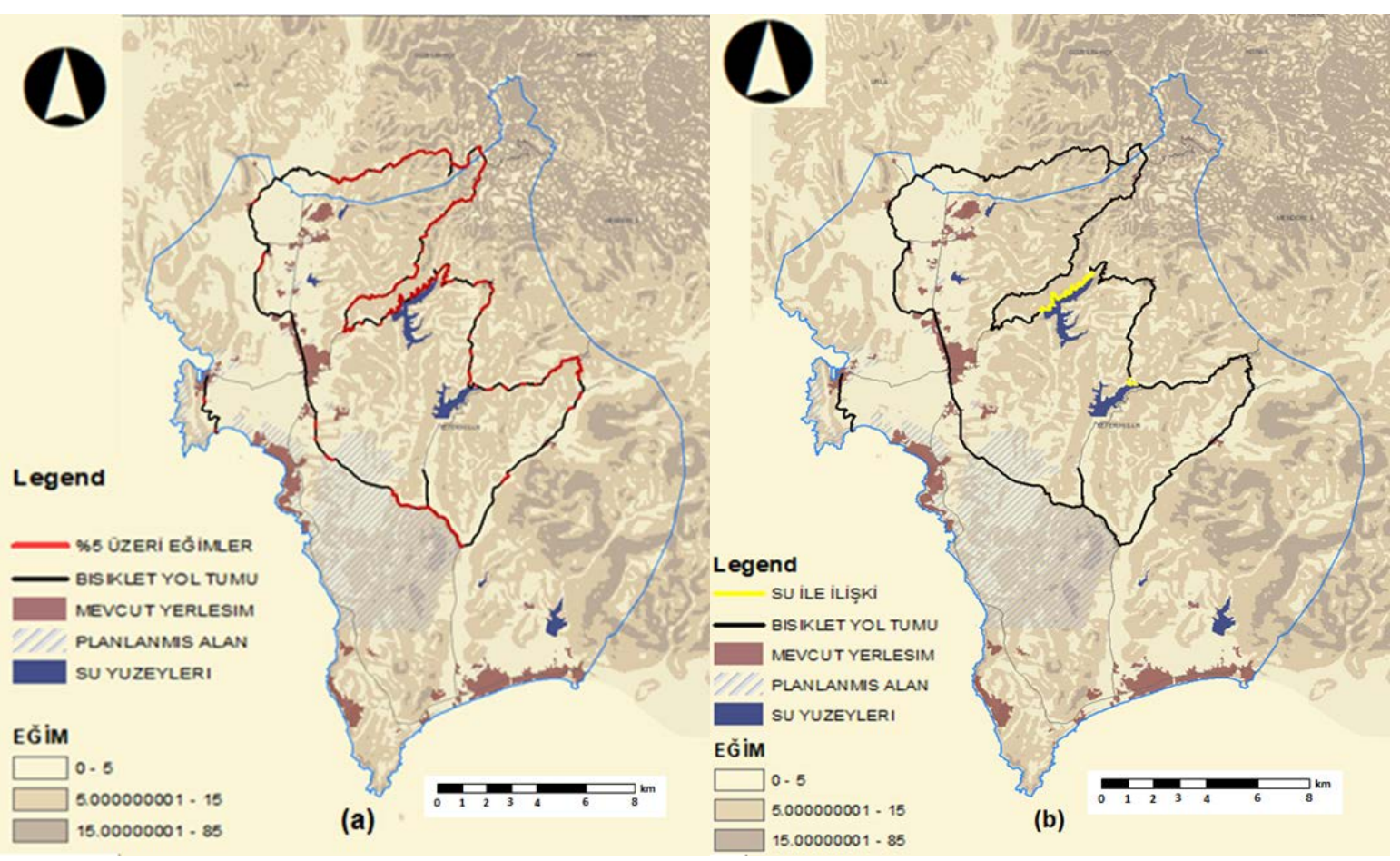

Şekil 5. Yüksek eğimli bisiklet güzergahları (a) ile su kütleleri ile ilişkili güzergahlar (b)

(Kazma, 2017, s. 96)

Bisiklet Yolu Kılavuzu'nda da (2012) belirtildiği gibi, uzun mesafeli yollarda devamlılığı olan eğimlerin \%2 ile sınırlandırılması sürüş konforu açısından önemlidir. 150 metreye kadar \%5’i geçen eğimler sürüş konforunu etkilememektedir. Ancak, bu gibi durumlarda sürüş konforunu koruyabilmek için dik yollarda yol genişliğini arttıııma çalışmalarının yapılması ve bisikletlere ekstra manevra yapabilecekleri alanlarının sağlanması gerekmektedir. 


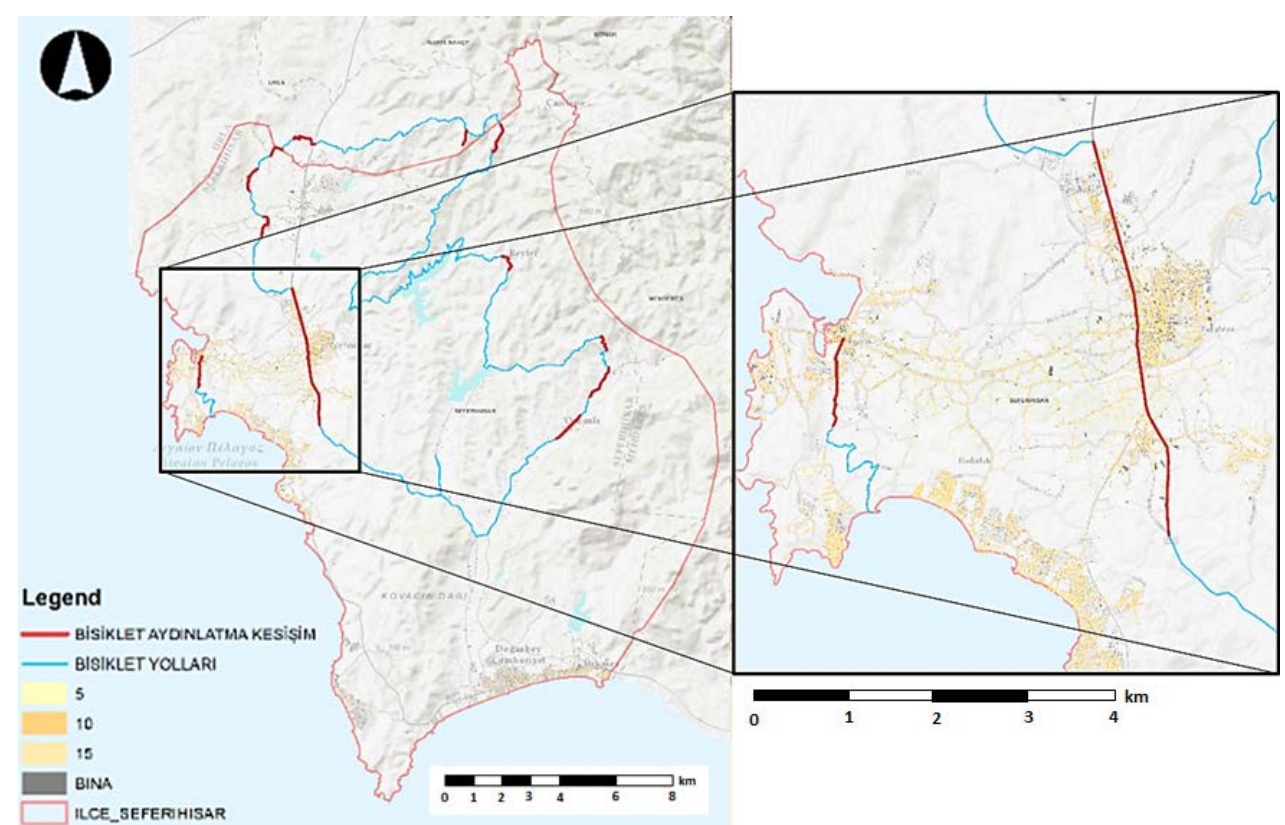

Şekil 6. Bisiklet yolları ve aydınlatılmış güzergahlar (Kazma, 2017, s. 97).

Seferihisar Belediyesi'nden elde edilen verilere göre yapılan analizler sonucu bisiklet yollarının aydınlatılmış alanlardan geçtiği bölgelerin genellikle kentsel yerleşim alanları olduğu görülmektedir. Şekil 6'da görülen analiz sonuçlarına göre, bisiklet yollarının aydınlatılmış alanlardan geçtiği güzergah uzunluğu yaklaşık 17.5 kilometre olup, toplam yolun \%18.9'una karşılık gelmektedir. Bu veriler kullanılarak gerçekleştirilen analizlerin sonuçları değerlendirildiğinde, çoğunluğu köy yerleşimleri ve Seferihisar merkezinden geçen hat üzerinde bulunmakta olan aydınlatılmış alanların, bisiklet güzergahlarının genel aydınlatma konforu açısından yeterli olmadığını göstermektedir.

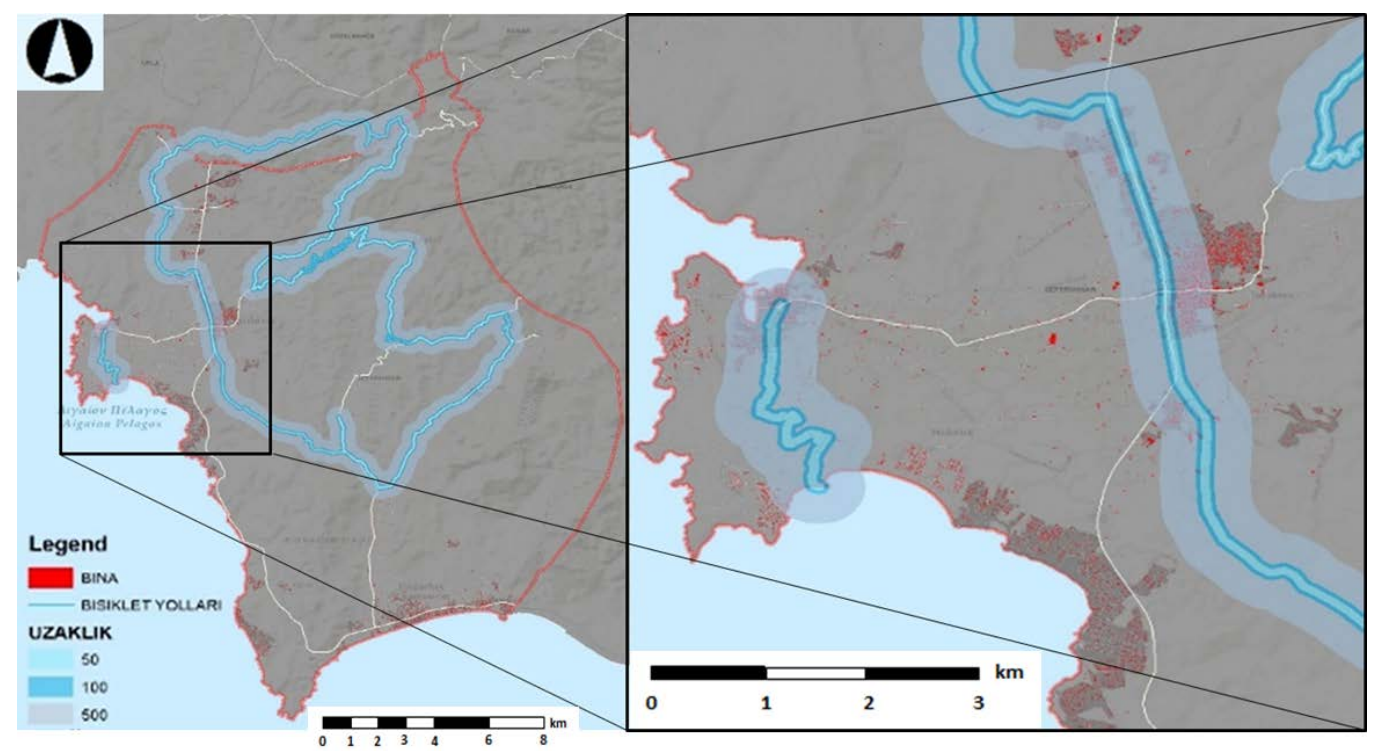

Şekil 7. Bisiklet yolları ve binalar arası uzaklık analizleri (Kazma, 2017, s. 98) 


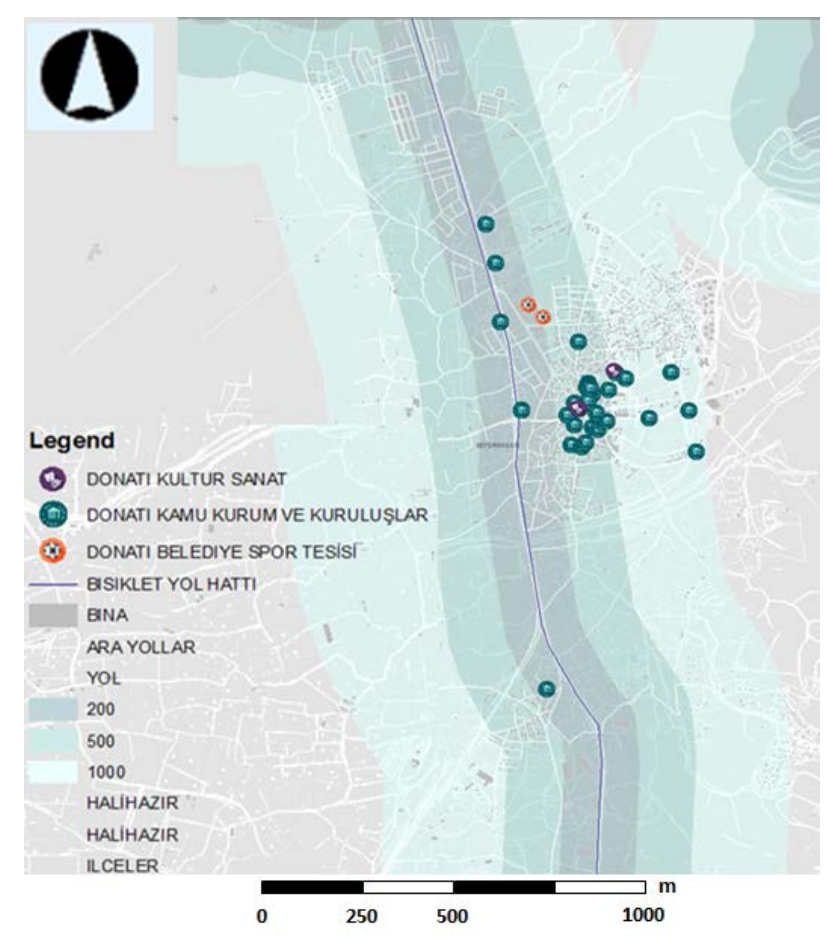

Şekil 8. Bisiklet yolları ve kamusal donatılar arası uzaklık analizleri (Kazma, 2017, s. 99).

Belediye planlarından elde edilen verilerle yapılan analizler sonucu, kent genelinde bisiklet yollarının; geçiş güzergahlarına 50 metrelik uzaklıkta 1465 adet binaya, 50-100 metre arası uzaklıkta ek 1112 binaya, 500 metre ve üzeri uzaklıkta ise toplamda 20037 binaya hizmet verdiği belirlenmiştir (Şekil 7).

Bisiklet yollarının Seferihisar kamusal donatıları ile olan ilişkileri incelendiğinde, bisiklet yollarına 200 metre uzaklıkta 14 kamusal donatı, 1 spor tesisi bulunduğu, 200-500 metrelik uzaklık içerisinde 25 adet kamusal donatı, 1 adet spor tesisi ve 2 adet kültür ve sanat merkezi bulunduğu, 500-1000 metre uzaklıkta ise 6 adet kamusal donatı ve 1 adet spor tesisi bulunduğu görülmüştür (Şekil 8).

Binaların ve mevcut kamusal donatıların bisiklet yollarına olan yakınlığının yanı sıra kişilerin bisikletleri ile bu yollara ulaşım durumu incelendiğinde, Seferihisar içerisinde herhangi bir mevcut kent içi bisiklet yolunun bulunmadığı ortaya çıkmıştır. En çok nüfus akışının gerçekleştiği Seferihisar merkezi ile Sığacık merkezi arasında bir bisiklet yolu bağlantısının olmaması, bisiklet yollarının yerli halktan çok, turistik amaçlı kullanıma yönelik tasarlandığını göstermektedir.

\section{SONUÇLAR}

CBS uygulamaları pek çok alanda olduğu gibi kent yönetimleri tarafından da (Türkiye'de Kent Bilgi Sistemleri şeklinde) kent yönetim-bilişim ve karar destek sistemi olarak kullanılmaya başlanmış olması, yerel yönetimlerde bu yönde bir farkındalığın oluştuğunun göstergesi sayılabilir.

Özellikle turizm yönünden bisiklet kullanımının cazip hale getirilip şehrin sürdürülebilir kalkınmasına katkı sağlanması bisiklet yol ve güzergahlarının konfor seviyelerinin yükseltilmesine bağlıdır. Bu bakış açısıyla yavaş şehir başkentimiz Seferihisar'ın mevcut bisiklet ağı CBS ortamında değişik kriterlere göre analiz edildiğinde aşağıdaki sonuçlar elde edilmiştir. 
Seferihisar Mevcut Bisiklet Güzergâhlarının CBS Ortamında Şehrin Dirençliliği Yönünden Yavaş Şehir Kriterlerine Göre Değerlendirilmesi

Evaluation of Current Bike Roads of Seferihisar According to Slow City Criteria for City Resilience in GIS Environment

İlk olarak Seferihisar'ın sahip olduğu biri 3.7 km ve diğeri $88.6 \mathrm{~km}$ olan iki adet yavaş bisiklet güzergahı konfor açısından doğal ortamla iç içeliği ve tarihi alanlar ile irtibatlandırılmaları analiz edildiğinde, ilkinde yavaş şehir kriterlerinde yer alan orman alanları ile bir ilişki kurulmadığı, diğerinde ise güzergahın yaklaşık \%28.3'ünün ormanlık alanlardan geçtiği, fakat bu güzergah üzerinde tarihi dokunun gözlemlenebildiği herhangi noktanın olmadığı görülmüştür.

Yine konfor açısından diğer bir kriter olan eğime göre, güzergahlar CBS ortamında analiz edildiklerinde toplam bisiklet yollarının \%40.5'inin \%5'lik eğime sahip olduğu ve bu durumun bisiklet yollarının yerleşim alanlarının dışında kaldığı bölgelerde gözlemlendiği ifade edilebilir. Bu nedenle mevcut bisiklet yollarının özellikle şehir dışında kalan kısımlarının, Bisiklet Yolu Kılavuzu'nda da (2012) yer alan "uzun mesafeli yollarda devamlılığı olan eğimlerin \%2 ile sınırlandırıması" şartına uymadığı için sürüş konforu açısından yetersiz kaldığı sonucuna varılmıştır. CBS ortamında, bisiklet yollarının su kaynakları ile olan ilişkisi analiz edildiğinde ise, kısa güzergahın bu kaynakların yakınından hiç geçmediği diğer güzergahta ise sadece iki noktada ve \%7.1'lik bir oranla böyle bir bağlantının oluştuğu gözlemlenmiştir.

Diğer bir analiz de, bisiklet güzergahlarının aydınlatılmışlık oranını belirlemek için yapılmış olan analizleri içermekte olup, güzergahların toplam aydınlatılmışlık oranının yaklaşık $\% 0.2$ 'de kaldığı ve bu bölgelerin de genellikle yerleşim alanları ile kısıtlı olduğu görülmüştür.

Bunların dışında mevcut bisiklet yolları şehre yeterlilik açısından analiz edildiklerinde bisiklet yollarına 500 metre mesafede yaklaşık 20000 binaya hizmet verilebileceği, spor tesisleri ile kültür sanat merkezlerine yeterlik açısında kısıtlı kalsalar da, kamu donatılarına yakınlık açısından 35 donatıya yakın oldukları sonucuna varılmıştır.

Binaların ve mevcut kamusal donatıların bisiklet yollarına olan yakınlığı açısından Seferihisar yukarıda belirtilen bir tabloya sahip olsa da, kentsel alanlarda yaşayan veya her ne sebeple olursa olsun bulunan kişilerin bisikletleri ile bu yollara ulaşım durumu incelendiğinde, Seferihisar içerisinde herhangi bir mevcut kent içi bisiklet yolunun bulunmaması, hatta en yoğun nüfuz hareketliliğinin görüldüğü Seferihisar merkezi ile Sığacık merkezi arasında bile herhangi bir bisiklet yolu bağlantısının planlanmış dahi olmaması, bisiklet yollarının yerli halktan çok, turistik amaçı kullanıma yönelik tasarlandığını göstermekte olup şehrin ekodayanıklılık açısından yetersiz olduğu sonucunu ortaya koymaktadır.

Bütün bu veriler birlikte değerlendirildiğinde Seferihisar'ın yavaş şehir bisiklet güzergahı kapsamındaki kriterlere ve yukarıda verilen CBS analiz sonuçlarına göre kısıtlı bir bisiklet güzergahı hizmetine sahip olduğu çıkarımı yapılabilir. Bisiklet yolları açısından CBS analizleri ile kuantitatif olarak belirlenen bu kısıtın giderilmesi için, çalışma kapsamında gerçekleştirilen analizler neticesinde ortaya çıkan sonuç durum üzerinden yapılacak değerlendirmeler ve yine CBS aracılığıyla yüksek güvenirlikle verilebilecek öneriler ışığında, kentin bisiklet yolları bağlamında daha iyi noktalara taşınması için alınacak tedbirler ve oluşturulacak eylem planları; kenti, daha "sakin" (slow), daha "sürdürülebilir" ve özellikle de çevresel kriterler açısından daha "dirençli" hale getirecek ve çevre dostu yeni kalkınma imkanları oluşturarak kenti daha güçlü kılacaktır.

$\mathrm{Bu}$ çalışma, kente dair verilerin elde edilmesi ile yavaş şehir bağlamındaki üyelik kriterlerinden, bisiklet yollarının sağlanması kapsamındaki değerlendirmelerle kısıtlı tutulsa $\mathrm{da}$, ileride paylaşılacak olan, hanelerin sosyal altyapılar ile ilişkilerinin kontrolü, biyolojik çeşitliliğin korunması, otellerin kapasitelerinin kontrol edilmesi gibi diğer yavaş şehir üyelik kriter analizlerini de içermektedir. Analizler sonucunda, kentin gelecek planlamalarına, 
geliştirilmesi gereken alanların belirlenmesine, turizm odaklı gelişimlerde otel kapasitelerinin değerlendirilmesine, kentin yapılaşma yönünün ortaya çıkarılarak öngörüler oluşturulmasına, kentleşmenin biyolojik çeşitliliğe vereceği etkinin gözlemlenmesine, sosyal donatıların yerel halka ve turistlere yeterliliklerinin ve erişimlerinin kontrollerinin yapılmasına altyapı olabilecek örnek bir çalışma oluşturduğu düşünülmektedir.

\section{KAYNAKLAR}

Altun, A., (2011). Kentsel dayanıklılığın arttırılmasında sosyo-ekolojikilişki ağları ve yapılaşmanın rolü (Yüksek Lisans Tezi), ITÜ FBE, 116.

Aydoğan, S. (2015). Sürdürülebilir Mimarlıkta Sakin Şehir (Cittaslow) Yaklaşımı. (Yüksek lisans tezi). İstanbul Teknik Üniversitesi, Fen Bilimleri Enstitüsü, İstanbul.

Bisiklet Yolu Kılavuzu, (2012). Çevre Ve Şehircilik Bakanlığı Çevre Yönetimi Genel Müdürlüğü, Ankara.

Carmin, J., Nadkarni, N., \& Rhie, C. (2012). Progress and challenges in urban climateadaptation planning: Results of a global survey. Massachusetts Cambridge, MA,USA. http://web.mit.edu/jcarmin/www/urbanadapt/Urban Adaptation Report FINAL.pdf

Cittaslow Türkiye. (2020). Cittaslow Türkiye Akyaka Erişim: 2 Temmuz 2017 tarihinde http://cittaslowturkiye.org/cittaslow-akyaka/ adresinden erişildi.

Cittaslow. (2020). Cittaslow. 10 Nisan 2019 tarihinde http://www.cittaslow.org/ adresinden erişildi.

Cope, A. M., Doxford, D., \& Hill, T. (1998). Monitoring Tourism on the UK's First LongDistance Cycle Route. Journal of Sustainable Tourism, 6(3), 210-223. doi:10.1080/09669589808667312.

EcoGIS Consultants. (2000). Submission on cycle tourism to the Tourism Strategy Group. A report commissioned by the Cycling Promotion Fund of Australia and the Bicycle Federation of Australia.

Eskicioğlu, H., (2009). Modern Yaşam İle Geleneksel Yaşam Arasında Kaliteli Bir Yaşam Biçimi - Yavaş Şehirler. İzmirde Sanat. 07 Mayıs 2019 tarihinde http://www.izmirdesanat.org/yavas-sehirler/ adresinden erişildi.

European Commission Directorate General Tourism Unit - Accessibility in Tourism. 07 Ocak 2020 tarihinde http://ec.europa.eu/enterprise/sectors/tourism/accessibility/index_en.htm adresinden erişildi.

FAO. (1976). A framework for land evaluation. FAO Soils Bulletin No.32. Rome.

Kalkınma Bakanlığı, (2012). Türkiye Sürdürülebilir Kalkınma Raporu: Geleceği Sahiplenmek. Ankara: 1-76.

Folke, C. (2006). Resilience: The Emergence of a Perspective for Social-Ecological Systems Analyses. Global Environmental Change, 16, 253-267. http://dx.doi.org/10.1016/j.gloenvcha.2006.04.002.

Holling, C. S., (1973). Resilience and Stability of Ecological Systems, Annual Review of Ecology and Systematics, 4:1, 1-23.

IIED, World Commission on Environment and Development (1987). Our Common Future. Oxford: Oxford University Press. p. 27. ISBN 019282080X.

Kaya Bensghir, T. ve Akay, A., (2006). Bir Kamu Politika Aracı Olarak Coğrafi Bilgi Sistemleri (CBS): Türkiye'de Belediyelerin CBS Uygulamalarının Değerlendirilmesi. Çağdaş Yerel Yönetimler, 15(1), 31-46. 
Kazma, C.Ş. (2017). Seferihisar için yavaş şehir yaklaşımının CBS ortamında değerlendirilmesi (Yüksek Lisans Tezi). İzmir Katip Çelebi Üniversitesi, Fen Bilimleri Enstitüsü, 144.

Leanne Barron and Erin Gauntlett (2002). Stage 1 Report Model of Social Sustainability, WACOSS Housing and Sustainable Communities Indicators Project, Western Australian Council of Social Service, WACOSS web site www.wacoss.org.au, visited 29.01.2020.

Leichenko, R. (2011). Climate change and urban resilience. Current Opinion inEnvironmental Sustainability, 3(3), 164-168. http://dx.doi.org/10.1016/j.cosust.2010.12.014.

Meerow, S., Newell, J. P., Stults, M., (2016). Defining urban resilience: A review. Landscape and Urban Planning, 147, 38-49.

Millennium Ecosystem Assessment, (2005). Ecosystems and Human Well-being: Opportunities and Challenges for Business and Industry. World Resources Institute, Washington, DC.

Ndubisi, N.O. (2005). Effect of gender on customer loyalty: a relationship marketing approach, Marketing Intelligence \& Planning, Vol. 24 No. 1, pp. 48-61.

Li, X. \& Yeh, A.G.O. (2001). "Calibration of Cellular Automata by Using Neural Networks for the Simulation of Complex Urban Systems". Environment and Planning A, 33, 1445-1462.

Paul Peeters \& Stefan Gossling \& Susanne Becken, (2006). "Innovation towards tourism sustainability: climate change and aviation," International Journal of Innovation and Sustainable Development, Inderscience Enterprises Ltd, vol. 1(3), pages 184-200.

Ritchie, B. W., \& Hall, C. M. (1999). Bicycle Tourism and Regional Development: A New Zealand Case Study. Anatolia, 10(2), 89-112. doi:10.1080/13032917.1999.9686974.

Simpson, M.C., Gossling, S., Scott, D., Hall, C.M. and Gladin, E. (2008). Climate Change Adaptation and Mitigation in the Tourism Sector: Frameworks, Tools and Practices. UNEP, University of Oxford, UNWTO, WMO, Paris.

Tao, C.H. \& Wall, G. (2009). Tourism as a sustainable livelihood strategy. Tourism Management, 30(9), 90-98.

UN Office for Disaster Risk Reduction, (2007). Final Report for Hyogo Framework for Action. 07 Mayıs 2019 tarihinde http://www.unisdr.org/ adresinden erişildi.

UNWTO-UNEP-WMO, (2008). (UNWTO and UNEP and WMO (2008), Climate Change and Tourism: Responding to Global Challenges, (prepared by Scott, D., Amelung, B., Becken, S., Ceron, JP., Dubois, G., Gössling, S., Peeters, P. and Simpson, M.C.), UNWTO, Madrid, and UNEP, Paris.

Walker, B. H., J. M. Anderies, A. P. Kinzig, and P. Ryan (2006). Exploring resilience in social-ecological systems through comparative studies and theory development: introduction to the special issue. Ecology and Society 11(1): 12. [online] URL: http://www.ecologyandsociety.org/vol11/iss1/art12/. 